\title{
Ésik Szaboles
}

esik.szabolcs@lib.pte.hu

\section{Adatbázisok használatának és megtalálhatóságának elösegitése a PTE EKTK-ban}

\section{BEVEZETÉS•}

Jelen tananyag célja, hogy bevezesse az olvasót a Pécsi Tudományegyetem Egyetemi Könyvtár és Tudásközponton (a továbbiakban: PTE EKTK) keresztül az egyetemi polgárság részére szolgáltatott tudományos adatbázisok világába.

A tananyag bemutatja az elektronikus szakirodalmak elsődleges szolgáltatási felületeinek használatát és felhasználósegítő lehetőségeit, így bemutatásra kerülnek az adatbázisok és e-könyv csomagok felületei, továbbá az online információforrások távoli elérési lehetőségei is.

Érintjük továbbá az összevont metakeresőn és az online könyvtári katalóguson keresztül a föbb keresési trükköket is, így átfogóan mutatjuk be a könyvtár által kínált lehetöségeket.

\section{Tematika}

1. Az adatbázisokról általában

2. Az egyetemi könyvtár honlapján elérhető információforrások bemutatása (előfizetett és ingyenesen elérhető adatbázisok, ekönyvek)

3. Compass

4. Távoli elérés

5. Általános keresési stratégiák és módszerek bemutatása az online könyvtári katalóguson (WebPac) és az EDS rendszeren keresztül

• A szövegben elöforduló összes internetes hivatkozás letöltési és ellenörzési dátuma 2021. május 31. 


\section{AZ ADATBÁZISOKRÓL ÁLTALÁBAN}

Bár az adatbázis alapvetően egy informatikai fogalom, nem kell megijedni, ezúttal nem a felépítések, relációs adatmodellek és különböző lekérdező nyelvek világában mélyedünk el, sokkal inkább az a célunk, hogy bemutassuk, az egyetemi hétköznapok során mihez érdemes - és lehet is - nyúlni, ha szakirodalomra van szükség.

De csak a definíció kedvéért: az adatbázis az adatok rend(szer)ezett gyưjiteménye. Ennek a gyüjteménynek lényeges jellemzői, hogy feldolgozhatónak és (vissza)kereshetőnek kell lennie.

Nézzünk egy szemléltető példát: képzeljük el, hogy van egy kisebb helyiségünk, tele kézzel írt levelekkel. A borítékok fel vannak címkézve ugyan (címzett, feladó stb.), de a szobában ömlesztve vannak a levelek, nincs benne semmilyen rendszer. Ha ebből a halmazból csak azokra a levelekre lenne szükségem, amiket András írt Mirellának, hogyan tudnám ezeket kiválogatni?

Csakis úgy, ha egyesével, az összes borítékot megnézem és szortírozom, amelyik nekem kell. Azonban belátható, hogy ez rengeteg idő, és egyáltalán nem hatékony. Ha viszont csak annyi rendszert viszünk a dologba, hogy a feladókat ábécésorrendbe tesszük, a visszakereséskor máris könnyebb dolgunk lesz. Természetesen számtalan egyéb adatot is rögzíthetünk (címzett, nem, irányítószám stb.), csak arra kell figyelnünk, hogy ugyanazon módszertan szerint keressük vissza az adatokat, mint ahogy azok rögzítésre kerültek.

$$
* \quad * \quad *
$$

Nem állunk messze az igazságtól, ha azt mondjuk, a hétköznapok során úton-útfélen adatbázisokba botlunk. Ugyan nem feltétlenül ilyen szemmel közlekedünk a világban, de gondoljunk csak bele: hogyan nézünk meg egy vasúti vagy városi buszmenetrendet? Megnyitunk egy weblapot vagy alkalmazást, kikeressük a járat vagy megálló nevét, és lekérdezzük az ehhez kapcsolódó adatokat.

Hogyan rendelünk egy pendrive-ot egy webshopból? Kiválasztjuk (általában a bal oldalon található lehetőségek segítségével), hogy melyik márka mekkora kapacitású, milyen csatlakozású terméke érdekel, milyen árkategóriában, milyen jótállással, sőt, milyen színben.

Ezek mind-mind adatok, és ezen grafikus, felhasználóbarát rendszerek mögött mind adatbázisok vannak, csak már annyira a mindennapjaink részét képezik, hogy fel sem tünnek számunkra. 
Az élet egyébként is egy folyamatos információkeresés (gondoljunk csak bele, mennyire alapkészség már, hogy ha egy honlapon, egy PDF-fájlban vagy egy Word-dokumentumban keresünk egy konkrét szót, akkor reflexszerüen a CTRL+F kombinációhoz nyúlunk), mégsem mondjuk azt, hogy „információkeresést végzek egy adatbázisban naponta tizennyolcszor".

$\mathrm{Az}$ internet jóvoltából egyébként is végtelen mennyiségü információhoz férünk hozzá, ám pont emiatt ennek megvan a maga veszélye is: hatalmas a választék, de sok a „zaj” is; nem feltétlenül arra kapunk választ (az álhírek korában pláne megbízható választ), amit kérdeztünk.

Tehát a bőség zavarában, a too much information jelenség közepette tudnunk kell, hogyan kell keresni. Ebben tudnak segítséget nyújtani az információs szakemberek, azaz a könyvtárosok.

\section{A könyvtár szerepe}

A PTE-n tudományos adatbázist kizárólag az EKTK szerezhet be, a szervezeten belül pedig a konkrét munkát az ún. adatbázis referensek végzik.

Miben is merül ki ez a munka?

- IP-cím-nyilvántartás,

- tesztidőszakok keresése, intézése, hirdetése,

- adatbázisokhoz kapcsolódó oktatások, webinárok szervezése (külső: gólyatúra, adatbázis roadshow-k, belső: kollégáknak), külföldi előadókkal, trénerekkel való kapcsolattartás, webinárok hirdetése,

- adatbázisok tesztelése, hibaelhárítás, panaszkezelés,

- kapcsolattartás a kiadókkal magyarul és angolul,

- kapcsolattartás kollégákkal és különböző egyetemi szervezeti egységekkel,

- szerződéshosszabbítások és új szerződésekkel kapcsolatos tárgyalások,

- statisztikák készítése,

- fejlesztések,

- stb.

Mint látjuk, ez egy elég sokrétủ dolog, és több részével még a későbbiekben foglalkozni fogunk. 


\section{AZ EGYETEMI KÖNYVTÁR HONLAPJÁN ELÉRHETŐ INFORMÁCIÓFORRÁSOK BEMUTATÁSA (előfizetett és ingyenesen elérhető adatbázisok, e-könyvek)}

Ami elsőre lényeges a fentiek közül számunkra, az az a felület, amelyen közzétesszük az egyetem polgárai számára hozzáférhető adatbázisok listáját, más szóval: az Adatbázis portál.

\section{Az Adatbázis portál}

A portál elérhetősége a következő: https://lib.pte.hu/adatbazisok, de eljuthatunk ide úgy is, ha a könyvtár föoldaláról indulunk (https://www.lib.pte.hu), és onnan navigálunk a „Böngészhető tartalmak" lehetőségnél az E-könyvtárba, majd ott az Adatbázis portálra.
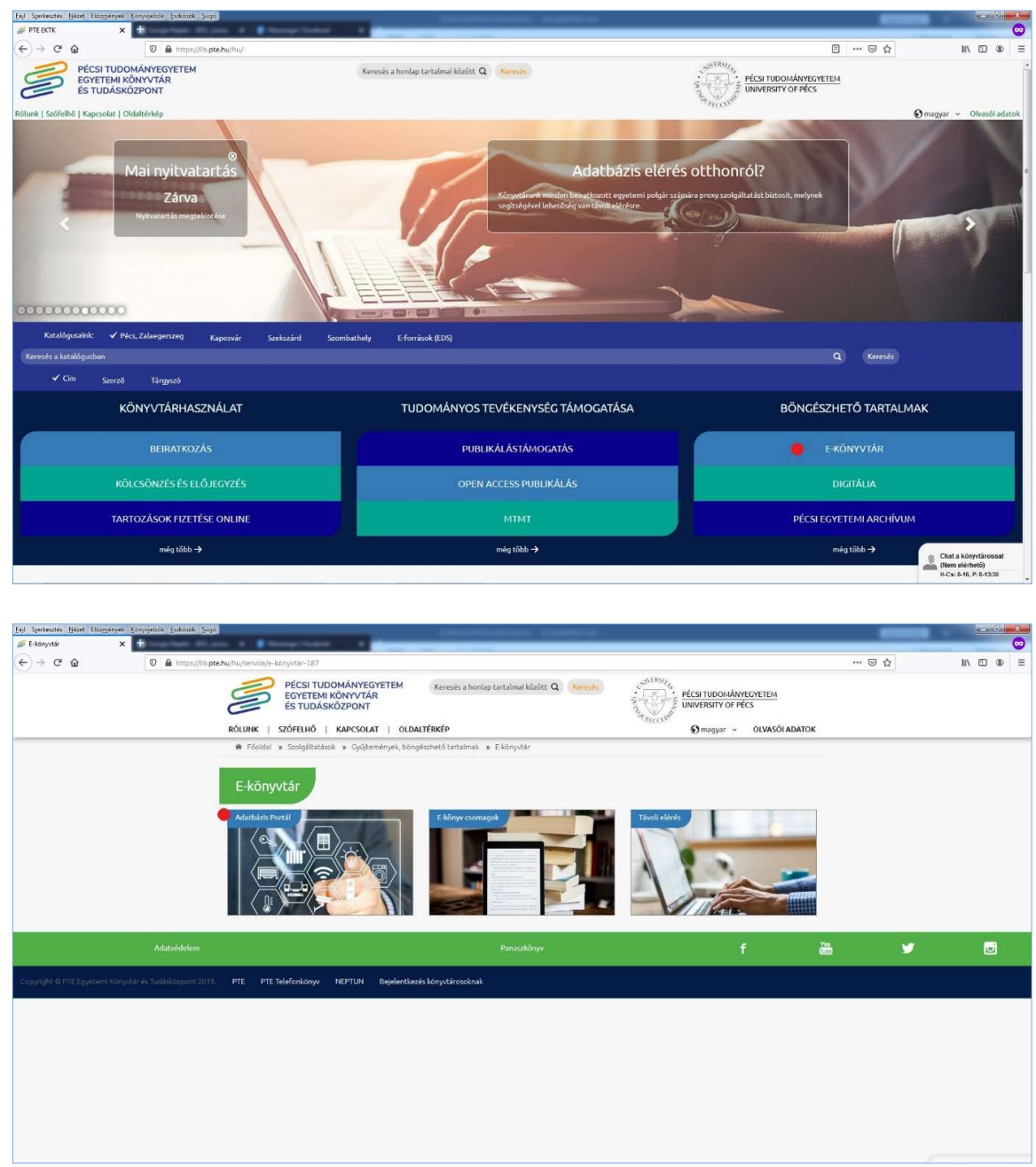


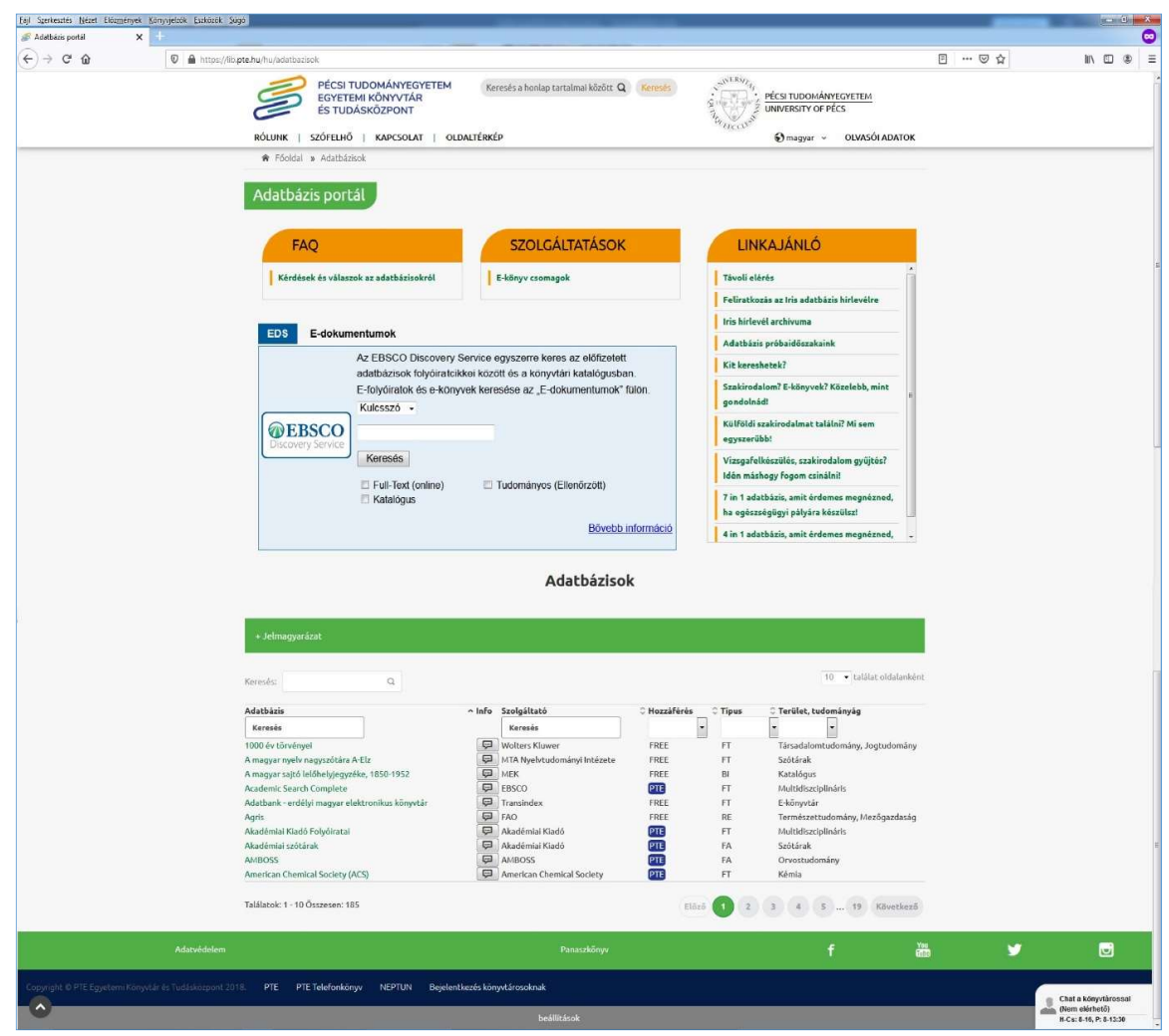

Itt megtaláljuk a gyakran ismételt kérdéseket (FAQ) és a kapcsolódó szolgáltatások dobozát, illetve számos, lényeges kapcsolódó hivatkozást. Az egyik központi helyet elfoglaló kék keresődobozról később lesz szó, most fókuszáljunk az oldal alján található adatbázislistára.

Maga a portál gyakorlatilag az adatbázisok adatbázisa. Mivel az oldalon általában 150+ adatbázis van listázva, el is kél némi segítség, ha el szeretnénk igazodni közöttük - ennek érdekében jelmagyarázat és minden oszlopnál keresési/szürési lehetőség áll rendelkezésre.

Igen ám, de hogy kerül ide ennyi adatbázis?

Itt érdemes kitérni arra, hogy pénzügyi szempontból vannak elöfizetéses és ingyenes adatbázisok. Mivel a legnagyobb tudományos adatbázisok több száz, sokszor több ezer tudományos, lektorált és adott esetben igen magas presztízsü szakfolyóirat 10-20-30 évnyi cikkeit tartalmazzák, ezek hatalmas gyüjtemények. (Amelyeknek a kiadók - amelyek nagyon is tisztában vannak azzal, hogy a tudományos élet és a kutatás alapjai ugyanezek a folyóiratok - sokszor meg is kérik az árát.)

Ezek beszerzése történhet kizárólag a PTE és a kiadó közötti szerződéskötés útján, de ennél jellemzőbb, hogy az Egyetem országos 
konzorcium résztvevőjeként tesz szert ezekre a tartalmakra. Ilyen konzorcium az MTA által koordinált EISZ (Elektronikus Információszolgáltatás Nemzeti Program), amely a hozzájuk társult intézmények számára (és ideérthetjük gyakorlatilag az összes magyar felsőoktatási intézményt illetve közgyüjteményt) nemzeti licencvásárlás útján ad hozzáférést, tehát egy személyben képvisel mindenkit, akinek az adott adatbázisra szüksége van.

Az összes, portálon lévő adatbázisnak általában mintegy 1/3-a szokott előfizetéses adatbázis lenni. Ezeket a „Hozzáférés” oszlopban a „PTE” címke jelöli.

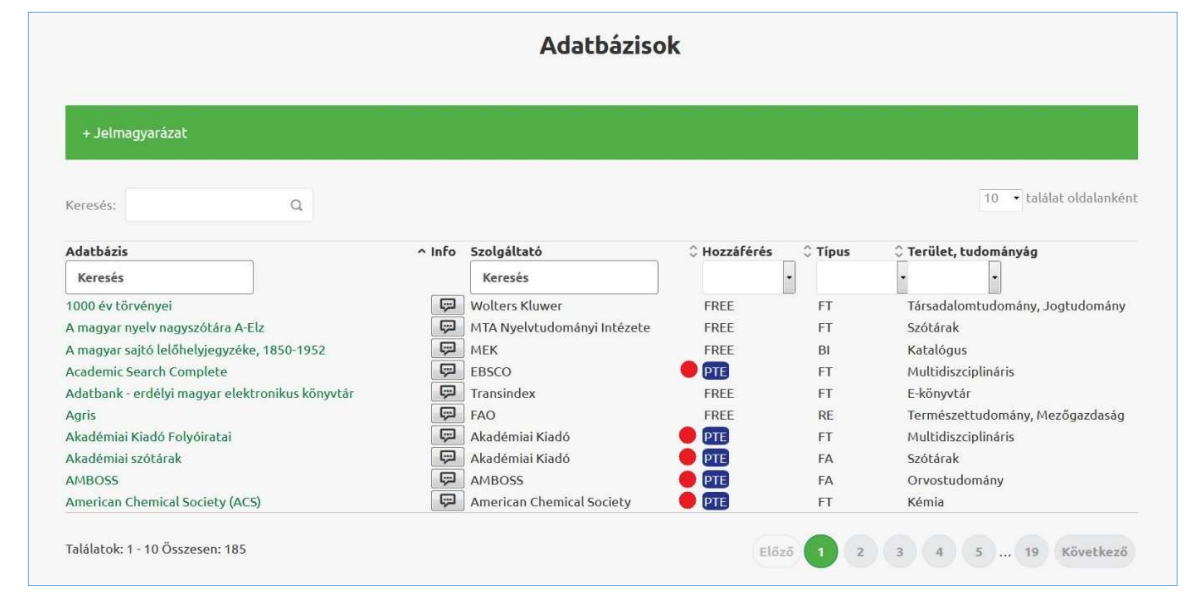

Azonban az egyetemi élet során nem csupán ezeket az adatbázisokat lehet hasznosítani; a portálra számtalan olyan gyüjteményt is felviszünk még, amely valamilyen módon hozzájárulhat az egyetemen folyó oktató, kutató, gyógyító és müvészeti tevékenységhez. Ezek az ingyenes adatbázisok, amelyekre a „FREE” címke kiválasztásával szürhetünk. 


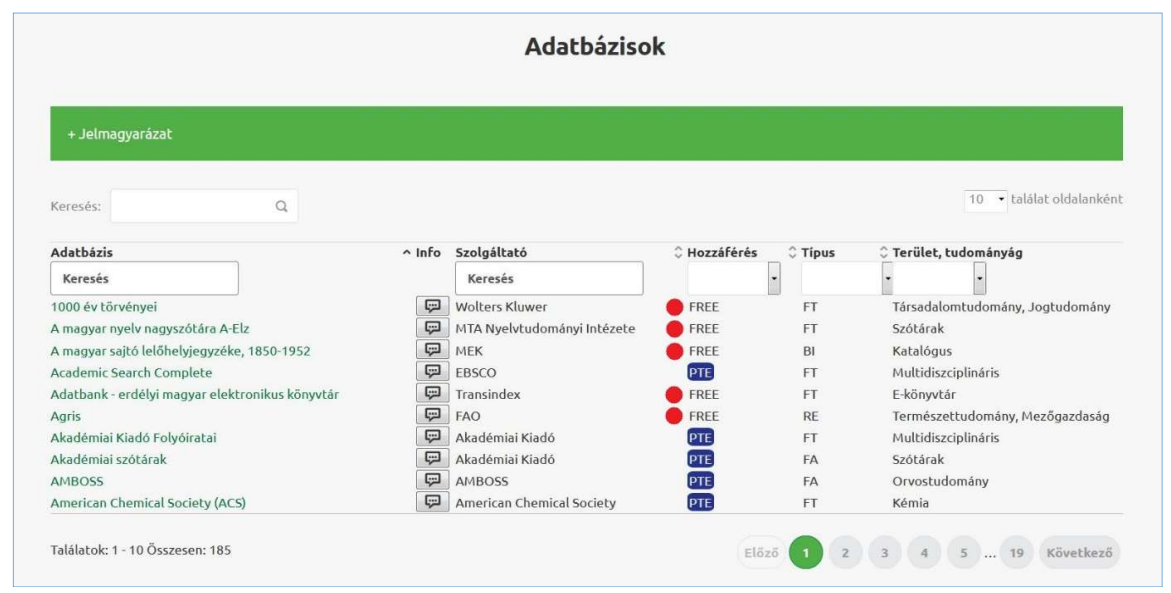

A „Hozzáférés” oszlopunkban van ugyanakkor a hagyományos előfizetett/ingyenes pároson kívül egy további kategória is: ezek a „TEST” jelzésű, korlátozott ideig kipróbálható adatbázisok.

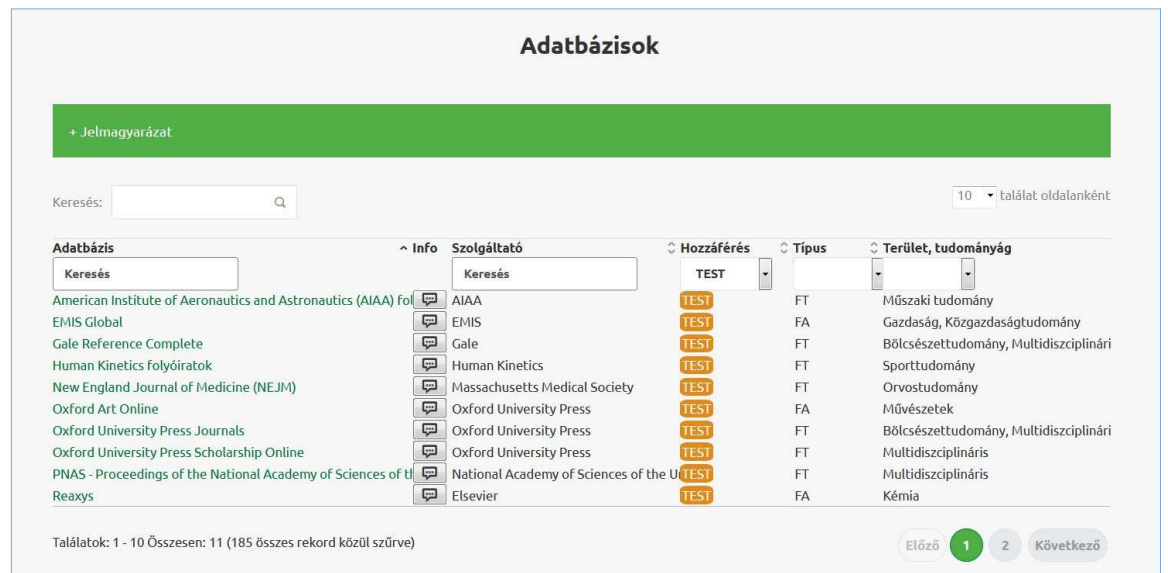

Könyvtárunk ugyanis az online elérhető, elektronikus dokumentumokhoz rövidebb, jellemzően 30-60 napig tartó ideiglenes eléréssel is igyekszik hozzáférést biztosítani. Az ilyen próbaidőszakok (más szóval trial) jellemzői, hogy többnyire a kiadók és szolgáltatók ajánlják fel őket, amolyan a tartalomba való betekintés gyanánt. Ezeket érdemes kihasználni, hiszen így átmenetileg olyan tartalmakhoz is hozzá tud férni az egyetemi polgárság, amelyekhez másképp, hagyományos módon sok esetben nem.

De térjünk vissza az adatbázisok listájához.

A tételek alapértelmezetten alfabetikusan - az adatbázisok neve szerint - vannak felsorolva, de bármely másik oszlop szerint is rendezhetjük listánkat, vagy ha konkrétan tudjuk, mit keresünk, a görgetés alternatívájaként be is gépelhetjük azt. 


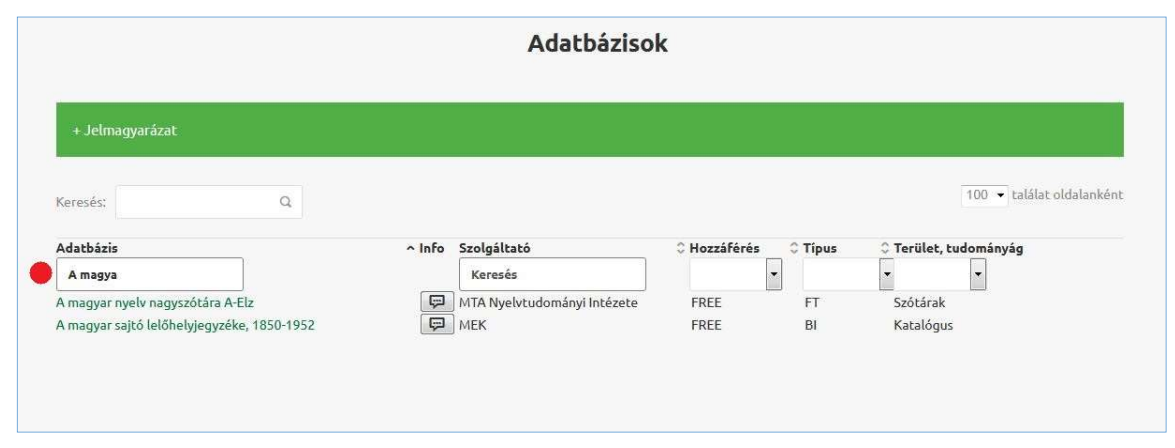

(A jobb áttekinthetőség érdekében érdemes beállítani, hogy egy oldalon minél több találatot jelenítsen meg a rendszer.)

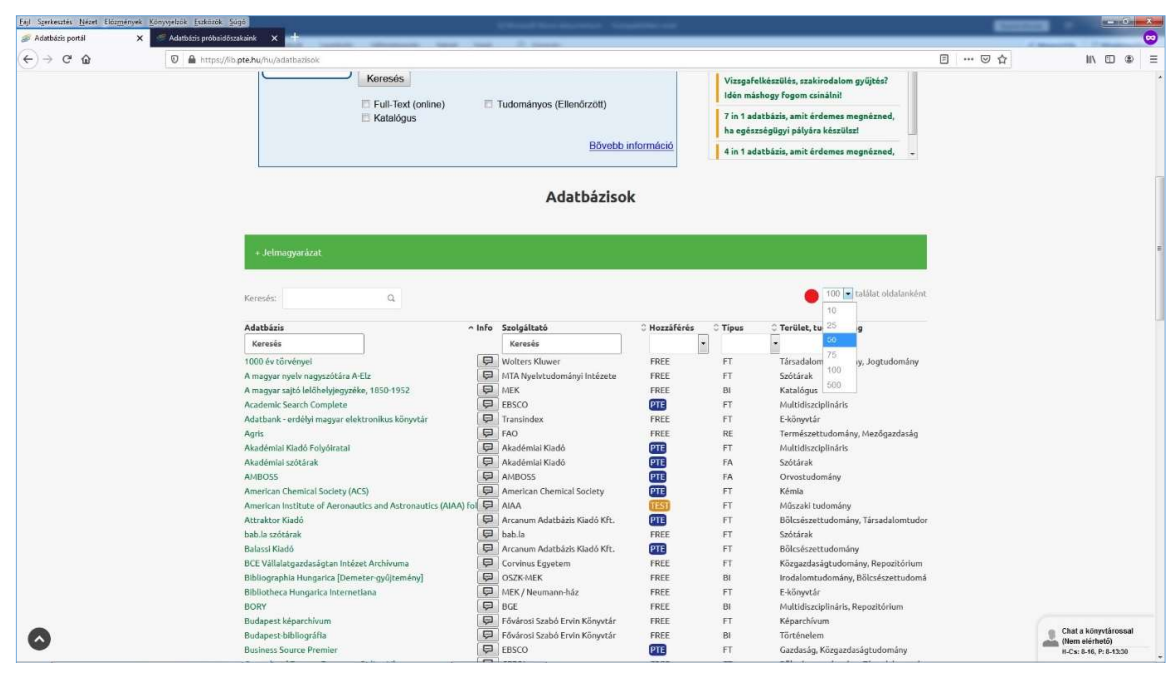

Az adatbázisok listája felett található „Jelmagyarázat” gombra kattintva egy lenyíló menü is segítségünkre van a táblázat oszlopainak részletezésében: a már említett PTE-FREE-TEST hármason kívül a négyféle forrástípus jelzésének magyarázatát is itt találjuk, amelyre szintén szürhetünk a vonatkozó oszlopban. 


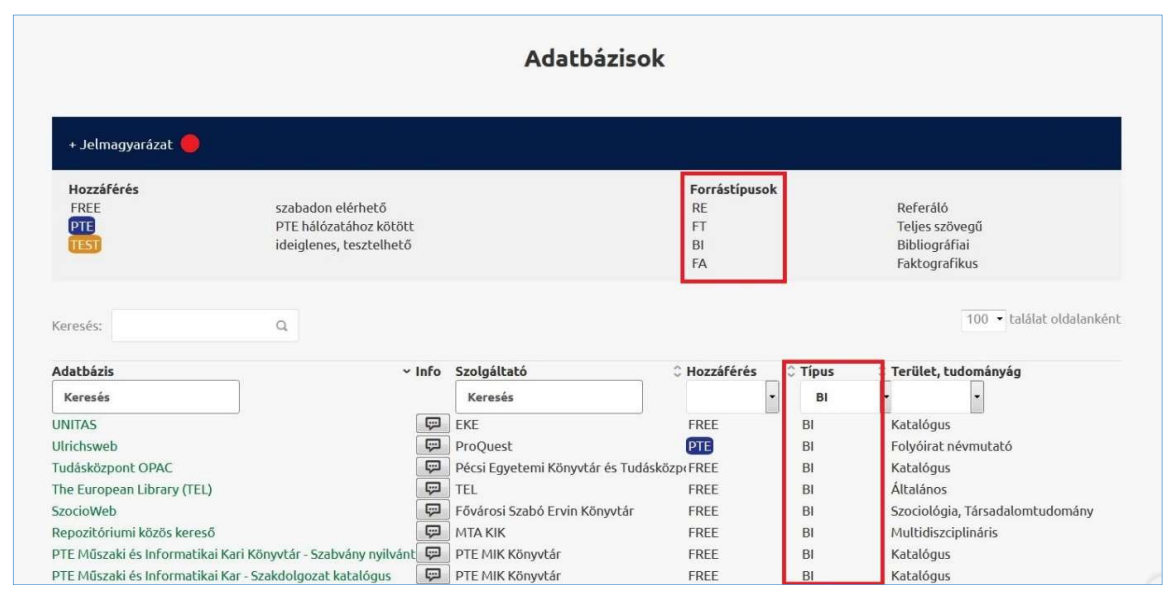

Az Adatbázis portálon ugyanis négy forrástípust különböztetünk meg, azaz egy-egy adatbázis lehet:

- teljes szövegü (a cikkek, tanulmányok teljes szövegéhez nyújt hozzáférést),

- referáló (a teljes cikkhez nem, csak azok absztraktjához ad hozzáférést)

- bibliográfiai (a főbb bibliográfiai adatok gyüjteménye) és

- faktografikus (tényalapú adatok, adattárak, szótárak, lexikonok).

Adatbázis-listánknak két hasznos tulajdonsága van még, az ún. infofájl és a szakterületi szürés.

Mivel pusztán név és szolgáltató alapján felhasználónk számára talán nem triviális, melyik adatbázis pontosan mit is takar, mindegyikhez füzünk tartalmat kifejtő magyarázatot. Ez az „Info” oszlop kis üzenetikonjára való kattintással hívható elő: először egy kis előnézeti buborék jelenik meg, majd a „Tovább” lehetőségre való kattintással jutunk el a tényleges infofájlhoz.

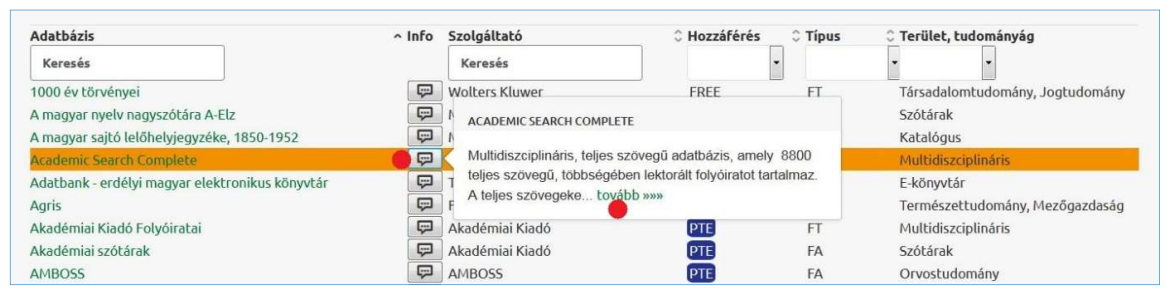

Ezen az aloldalon aztán elolvashatjuk, hogy aktuális adatbázisunk részletesen miből mennyi mindent tartalmaz - ha lehetséges, tételes címlistákkal együtt -, milyen otthoni hozzáférési lehetőségek vannak, továbbá a fó táblázatban is feltüntetett adatok újfent láthatók itt, va- 
lamint ahol elérhető, ott oktatóvideókat is igyekszünk beépíteni, így téve önálló felhasználásra is alkalmassá a gyüjteményt.

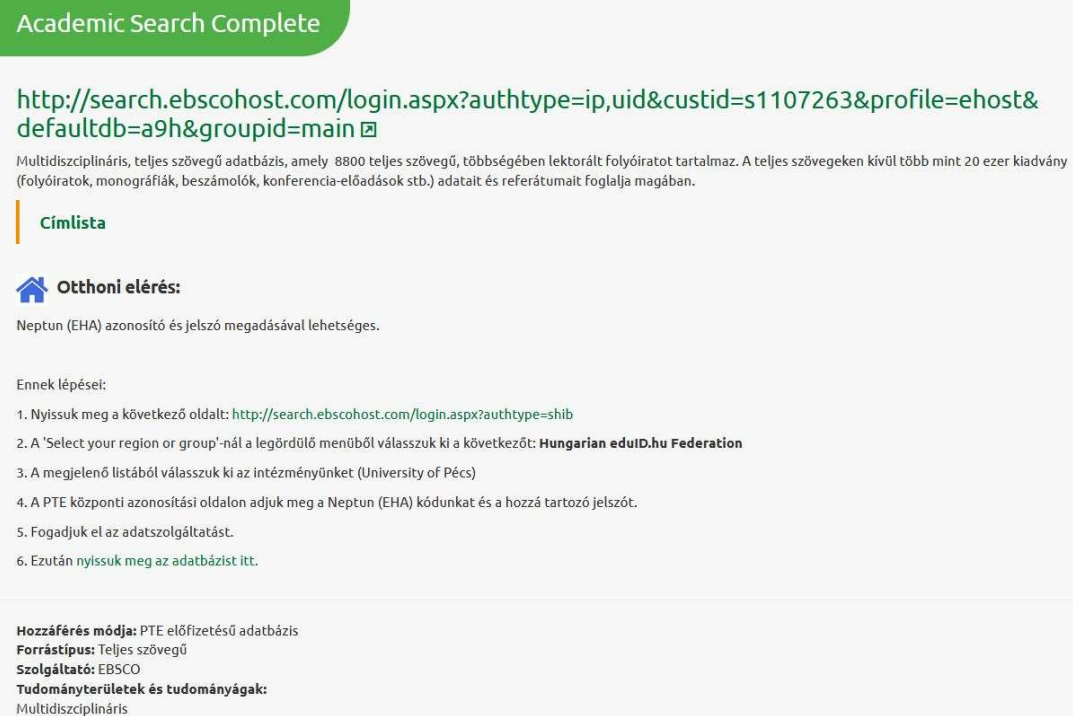

A korábban említett szakterületi szürés a fó táblázatunk „Terület, tudományág" oszlopának lenyíló menüjével érhető el. Ezzel érhetjük el, hogy ha egy konkrét tudományág vagy szakterület adatbázisait keressük, akkor ne egyenként kelljen megnézni, hogy az adott adatbázis nekünk való-e vagy sem, hanem egy egyszerü szüréssel lekérhetjük a számunkra releváns adatbázislistát.

Azon adatbázisok, amelyek több tudományterületet is felölelnek, a „multidiszciplináris” kategóriába kerülnek, de a releváns tudományterületekre szürve is megjelennek találatként.

\begin{tabular}{|c|c|c|c|c|c|c|}
\hline Adatbázis & \multirow[t]{2}{*}{ A Info } & Szolgáltató & \multirow{2}{*}{ \% Hozzáférés } & \multirow[t]{2}{*}{$\hat{v}$ Tipus } & \multicolumn{2}{|l|}{ Terület, tudományág } \\
\hline Keresés & & Keresés & & & - & \\
\hline 1000 év törvényei & 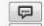 & Wolters Kluwer & FREE & FT & & \\
\hline A magyar nyelv nagyszótára A.Elz & 可 & MTA Nyelvtudományi Intézete & FREE & FT & Adatok a vilag országairól & \\
\hline A magyar sajitó lelöhelyjegyzéke, $1850-1952$ & 甲 & MEK & FREE & Bi & Audiovizualis archivum & \\
\hline Academic Search Complete & (口) & EBSCO & РTE & FT & Allatorvos-tudomany & \\
\hline Adatbank - erdélyi magyar elektronikus könyutár & (甲) & Transindex & FREE & FT & Általános & \\
\hline Agris & 四 & FAO & FREE & $\mathrm{RE}$ & Bölcsészettudomány & \\
\hline Akadémiai Kiadó Folyóiratai & 可 & Akadémiai Kiadó & एТT & FT & E-könyvtär & \\
\hline Akadémiai szótârak & 四 & Akadémiai Kiadó & एग्ड & FA & Egészségügy & \\
\hline AMBOSS & 四 & AMBOSS & PTE & FA & Európai televiziós archivum & \\
\hline American Chemical Society (ACS) & 甲 & American Chemical Society & PTE & FT & Életrajz & \\
\hline American Institute of Aeronautics and Astronautics (AIAA) fol & 四 & AIAA & (itsI & FT & Élettudomany & \\
\hline Attraktor Kiadó & 易 & Arcanum Adatbázis Kiadó Kft. & PTE & FT & Filmarchivum & \\
\hline bab.la szótárak & 可 & bab.la & FREE & FT & Filozófia & \\
\hline Balassi Kiadó & 可 & Arcanum Adatbázis Kiadó Kft. & एगि & FT & Folyoirat névmutato & \\
\hline BCE Vâllalatgazdaságtan Intézet Archívuma & 甲 & Corvinus Egyetem & FREE & FT & Forráskalauz & \\
\hline Bibliographia Hungarica [Demeter-gyü̈temény] & 㘡 & OSZKMEK & FREE & BI & Gazdaság & \\
\hline Bibliotheca Hungarica Internetiana & 旬 & MEK/Neumann-ház & FREE & FT & Hivatkozäsrendezó & \\
\hline BORY & 甲 & BGE & FREE & B) & Hirlapok & \\
\hline Budapest képarchivum & 男 & Fővárosi Szzabó Ervin Könywtár & FREE & FT & Idōszaki kiadvảnyok repertóriuma & \\
\hline Budapest-bibliográfia & 甲 & Fövárosi Szzabó Ervin Könyutár & FREE & BI & Irodalomtudomany & - \\
\hline Business Source Premier & & EBSCO & & $\mathrm{FT}$ & Gazdaság, Közgazdaságtudomány & \\
\hline
\end{tabular}




\begin{tabular}{|c|c|c|c|c|c|}
\hline Adatbázis & \multirow[t]{2}{*}{$A$ Info } & Szolgáltató & \multirow[t]{2}{*}{ V Hozzáférés } & $\hat{v}$ Típus & ̂̀ Terület, tudományág \\
\hline Keresés & & Keresés & & & - Bölcsészet. \\
\hline Attraktor Kiadó & 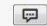 & Arcanum Adatbázis Kiadó Kft. & PTE & FT & Bölcsészettudomány, Tórsadalomtudor \\
\hline Balassi Kiadó & 罚 & Arcanum Adatbázis Kiadó Kft. & PIE & $\mathrm{FT}$ & Bölcsészettudomány \\
\hline Bibliographia Hungarica [Demeter-gyöjtemény] & 罒 & OSZK-MEK & FREE & $\mathrm{BI}$ & Irodalomtudomány, Bölısészettudomá \\
\hline Central and Eastern European Online Library & 䍐 & CEEOL & FREE & FT & Bölcsészettudomány, Társadalomtudor \\
\hline Digitális Irodalmi Akadémia (DIA) & 四 & Petôfi Irodalmi Múzeum & FREE & $\mathrm{FT}$ & Irodalomtudomány, Bölcsészettudomá \\
\hline Egyházi könyutárak keresörendszere (Theca) & 品 & OIK & FREE & $\mathrm{BI}$ & Bölcsészettudomány \\
\hline ERIC & 罚 & EBSCO & PTE & $\mathrm{RE}$ & Bölcsészettudomány, Neveléstudomán \\
\hline Gale Reference Complete & (D) & Gale & IESII & FT & Bölcsészettudomány, Multidiszciplinári \\
\hline Humántudományi Tanulmányok és Gikkek Adatbázisa (HUMAI) & $|A|$ & oszk & FREE & BI & Bölcsészettudomány \\
\hline Irodalmi kritikák, tanulmányok bibliográfiajja & 四 & Fővárosi Szabó Ervin Könyvtár & FREE & $\mathrm{BI}$ & Irodalomtudomány, Bôlcsészettudomá \\
\hline Jstor (Essential Collection) & 䁲 & Jstor & PTE & FT & Bölcsészettudomány, Társadalomtudor \\
\hline Kortárs & 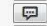 & Arcanum Adatbázis Kiadó Kft. & PTE & FT & Bölcsészettudomány, Irodalomtudomá \\
\hline Kossuth Kiadó & (D) & & PTE & FT & Bölssészettudomány \\
\hline L'Harmattan Digitális Adatbázis & 䁲 & Arcanum Adatbázis Kiadó Kft. & PTE & FT & Társadalomtudomány, Bölcsészettudor \\
\hline Magyar halotti kôltészet a 17. században & 甲 & ELTE & FREE & $\mathrm{BI}$ & Irodalomtudomány, Bölcsészettudomá \\
\hline Magyar Nemzeti Levéltár online adatbázisai & 罯 & Magyar Nemzeti Levéltár & FREE & FT & Bölcsészettudomány, Történelem \\
\hline Magyarország képes törtẻnelmi kronológiája & 罾 & OSZK-EHE & FREF & FT & Történelem, Bölcsészettudomány \\
\hline Mentor Könyvek Kiadó & 品 & Arcanum Adatbázis Kiadó Kft. & PTE & FT & Bölcsészettudomány, Irodalomtudomá \\
\hline National Archives of Japan & 四 & JACAR & FREE & FT & Bölcsészettudomány \\
\hline Osiris Kiadó & p & Arcanum Adatbázis Kiadó Kft. & PTE & FT & E-könyvtár, Bölssészettudomány, Törté \\
\hline Oxford University Press Journals & 罾 & Oxford University Press & |IES| & FT & Bölcsészettudomány, Multidiszciplinári \\
\hline Pedagógiai Adatbázis (PAD) & 䍘 & OPKM & FREE & $\mathrm{BI}$ & Pedagógia, Bölcsészettudomány \\
\hline Russian elibrary & 罳 & LANY & FREE & FT & Bölcsészettudomány \\
\hline
\end{tabular}

Az Adatbázis portál leglényegesebb része tehát a névadó lista maga, de az oldal tetején lévő Linkajánló doboz is számos fontos és hasznos szolgáltatást rejt. 


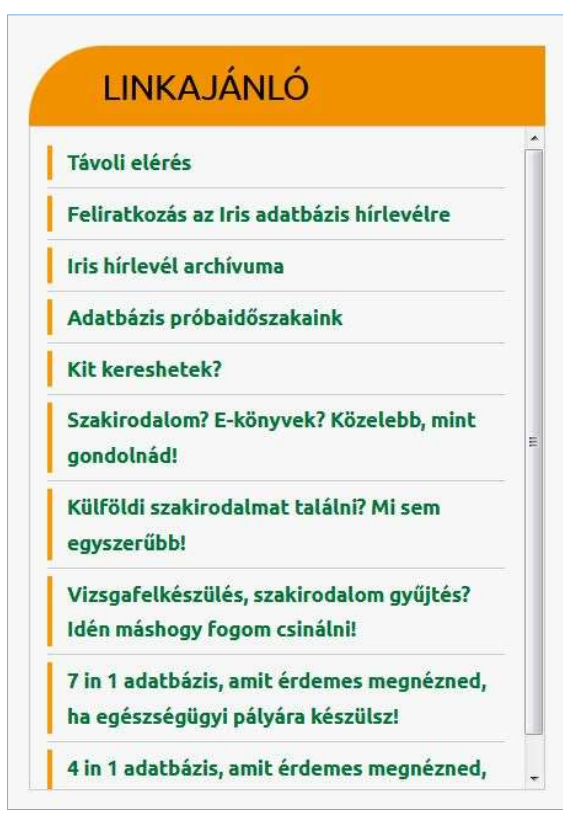

Itt találjuk ugyanis külön is kilistázva a próbaidőszakokat (,Adatbázis próbaidőszakaink"), a kapcsolattartási információkat („Kit kereshetek?"), a MyLib nevü könyvtári blogra írt, adatbázis témájú felhasználósegítő posztokat, valamint a távoli elérés illetve Iris hírlevelünk linkjeit is.

Ugyanis utóbbi segítségével is igyekszünk tájékoztatni a hírlevélre feliratkozott olvasókat a PTE EKTK ideiglenesen tesztelhetö, illetve újonnan beszerzett adatbázisairól, az ezekhez kapcsolódó aktuális rendezvényekről és webinárokról, valamint az Open Access Publis-

hing Irodához kapcsolódó eseményekröl.

\section{E-könyv csomagok}

Adatbázist természetesen rengeteg különféle adatból lehet építeni, legyenek azok folyóiratcikkek, szabadalmak, képek, videók, kémiai reakciók, gyógyszerhatóanyagok vagy e-könyvek. Habár a PTE-n mindegyik felsorolt típus képviselteti magát, azért a folyóiratok mellett még az e-könyves adatbázisok találhatóak meg a legnagyobb számban.

E-könyv alatt természetesen nem kizárólag a Kindle-re letölthetö, .epub vagy .mobi fájlkiterjesztésü e-könyveket értjük, hanem azokat is ide soroljuk, amelyeknél az anyag (azaz a szöveg) .html vagy .pdf formátumban van. Mindegyiknek megvan a maga előnye, utóbbi kettőé a gyakorlatilag eszközfüggetlen használhatóság. A tudományos ekönyves adatbázisok többnyire a .html-t és a .pdf-et használják.

A PTE által hozzáférhető e-könyv csomagok (ezeket jobbára kiadói csomagként szerezzük be, nem pedig egyenként, innen az elnevezés) megtalálhatóak az Adatbázis portál listájában is, de egy dedikált aloldalt is kaptak, amely a „szokásos” Könyvtári honlap $\rightarrow$ Böngészhetö tartalmak $\rightarrow$ E-könyvtár, majd E-könyv csomagok útvonalon található. Linkje: https://lib.pte.hu/e-konyvcsomagok

Ezen az aloldalon három főbb csoportban (Elsődleges források, Az EKTK saját digitalizálása, Külső források) minden, a PTE EKTK 
által beszerzett és/vagy digitalizált e-könyv megtalálható, a már ismert üzenet logós infofájlokkal egyetemben.

Folyamatosan bővülő gyüjtemény, érdemes meglátogatni!

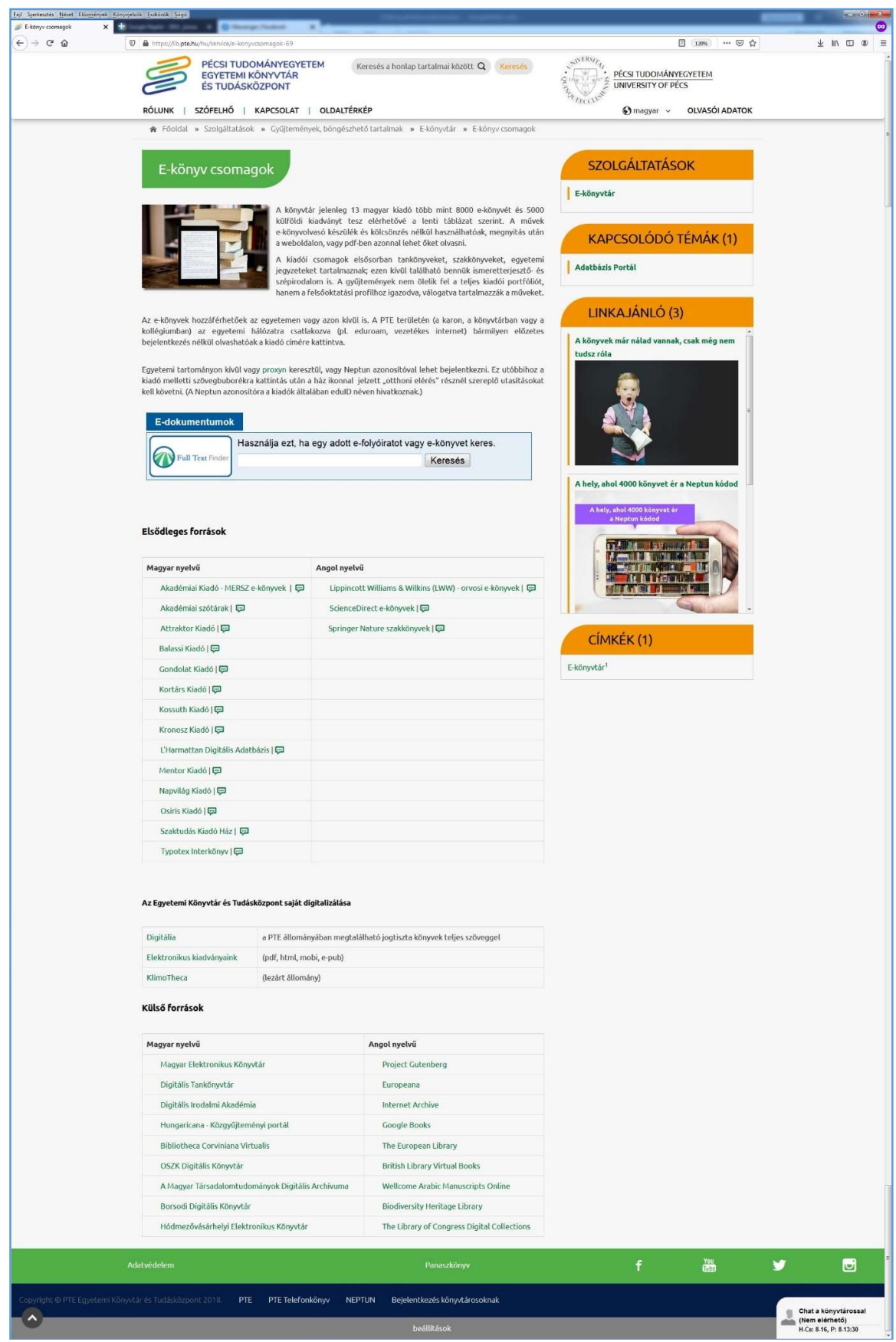




\section{COMPASS}

Következő pontunk, a távoli elérés előtt még teszünk egy rövid kitérőt egy olyan platformra, ahol megtalálhatjuk, hol érhető el egy-egy tudományos tartalom az országban, ha a PTE-n nem. Ez a platform a COMPASS (https://compass.mtak.hu).

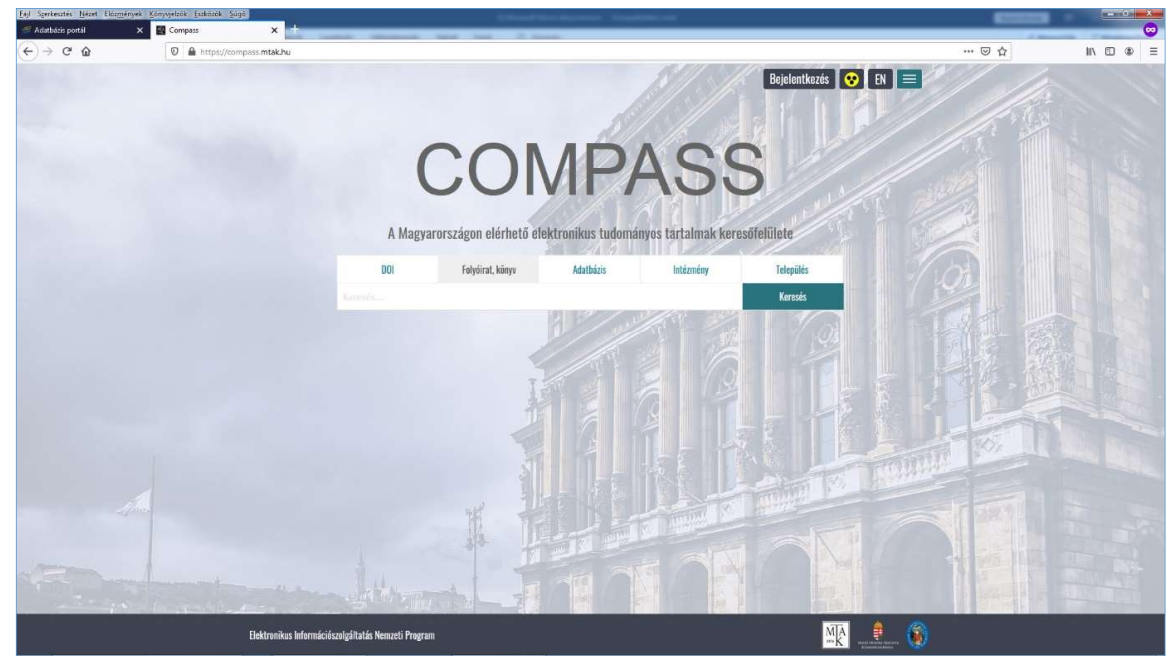

Ez a felület nem a PTE, hanem az MTA-KIK fejlesztése, az oldalon pedig lehetőségünk van keresni DOI-ra (Digital Object Identifier minden elektronikus dokumentum egyedi, digitális azonosítószáma), folyóiratra ill. könyvre, adatbázisra, intézményre, illetve településre.

Vegyünk egy egyszerü példát: anyaggyüjtést végzek egy folyamatban lévő kutatásomhoz, és a SAGE kiadóhoz tartozó folyóiratokra lenne szükségem.

Hogyan tehetem ezt meg?

Elöször is, választhatok, hogy nyomtatva vagy elektronikus formában van-e szükségem az anyagra. (Természetesen ez függ attól is, mikor és hol szeretnék hozzáférni.)

A print verziókat értelemszerüen valamely egyetemi könyvtári egységben kell keresnem, az online-okért pedig megnézem az Adatbázis portált, van-e hozzáférés valamilyen SAGE nevü adatbázishoz (előfizetett, ingyenes vagy időszakos). Ha nincs, akkor érdemes ellátogatnom a COMPASS oldalára. 


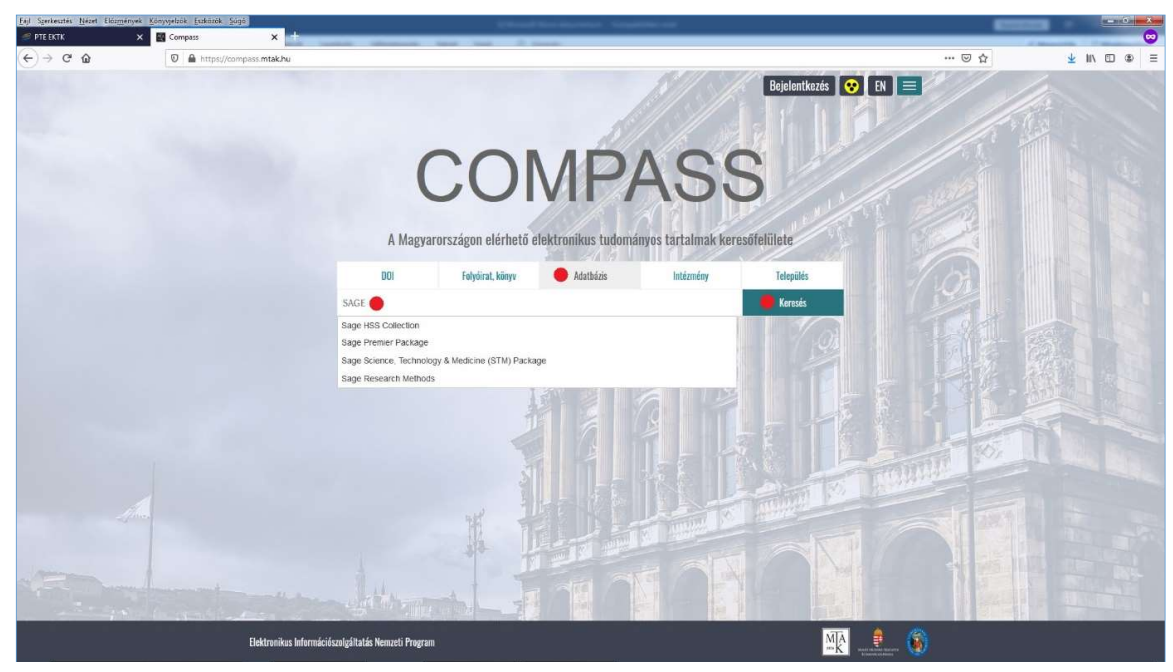

Ott kiválasztom, hogy adatbázist keresek (vagy ha konkrét folyóiratot, természetesen az is jó, sőt, ha konkrét cikket, mert arra is tudok DOI alapján keresni), elkezdem begépelni a „SAGE” szót, majd a keresésre kattintva megkapom a találati listát.

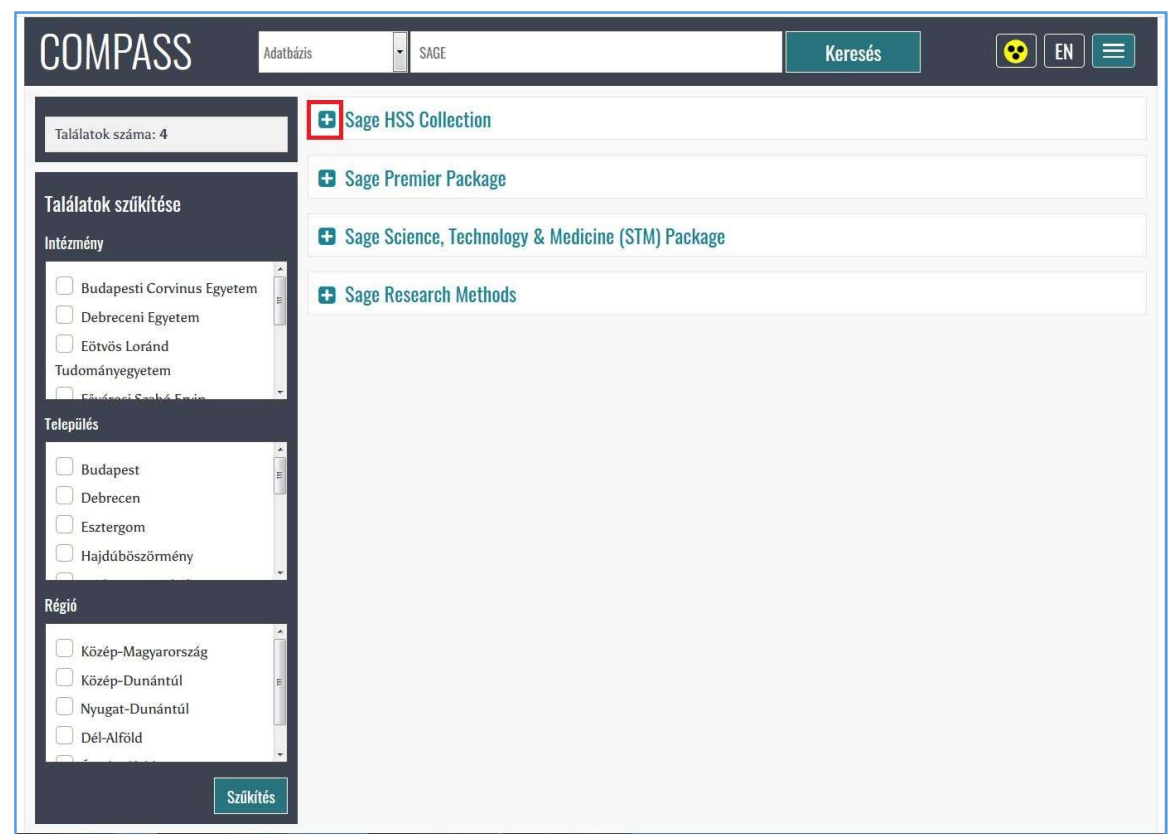

Itt a nekem megfelelő gyüjteményre kattintva lenyílik a menü, és azon belül az „Előfizetők” lehetőségre kattintva máris láthatom, hogy az országon belül ki és hol fizet elő a SAGE HSS (Humanities and Social Sciences) gyüjteményére. Így tudom azt például, hogy könyv- 
tárközi szolgáltatás keretein belül honnan érdemes cikket kérni, vagy melyik könyvtárba érdemes betérnem, ha esetleg egyébként is arrafelé lenne dolgom.

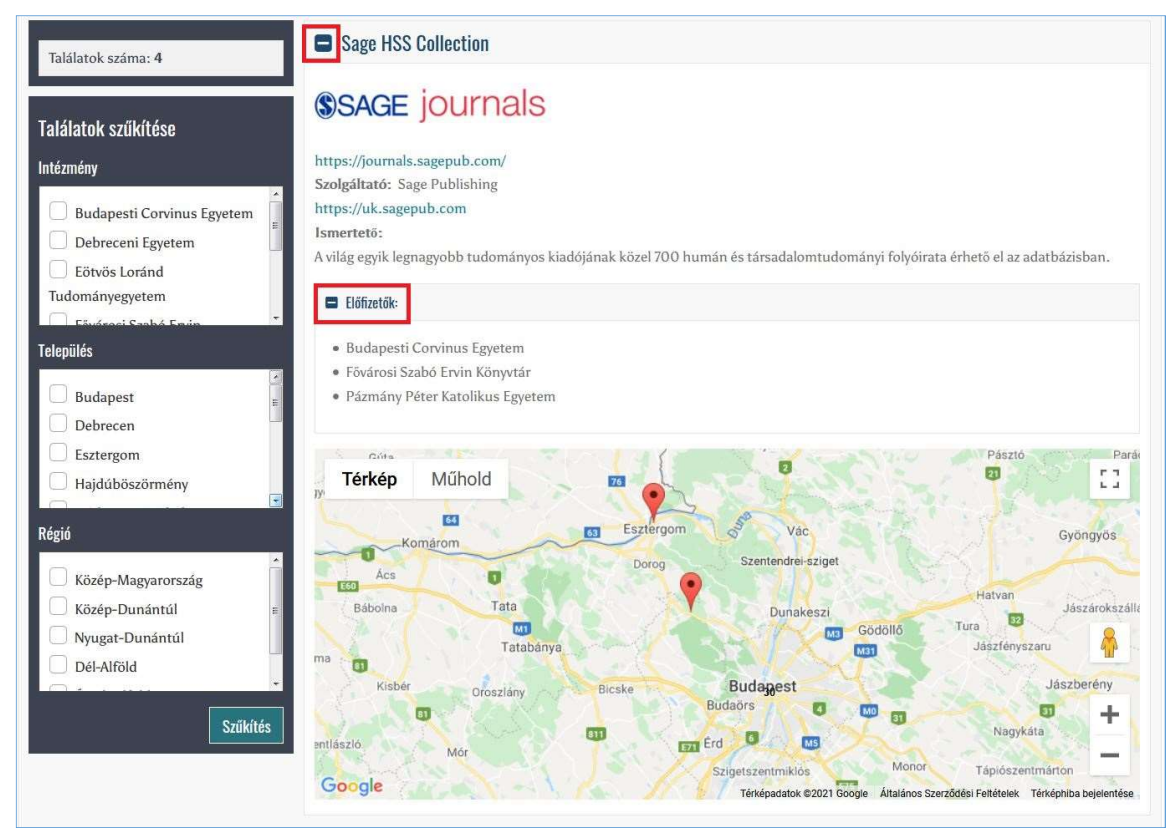

Természetesen számtalan olyan forgatókönyv is felmerülhet, hogy egy tartalomra van PTE-s hozzáférés, ám én pont nem tartózkodom olyan helyen (az egyetemen vagy a városban), hogy a tartalmakhoz hozzá tudnék férni.

Szerencsére erre is van megoldás! 


\section{TÁVOLI ELÉRÉS}

Míg a nyomtatott dokumentumok lokálisan kötöttek, addig az edokumentumok szolgáltatása online, az interneten keresztül történik. Ez abból a szempontból könnyebbség a felhasználók számára, hogy a gyüjtemény ezen részét a könyvtári hálózat egységeinek fizikai felkeresése nélkül is használhatják, sokszor akár anélkül is, hogy tudnák, amit igénybe vesznek, az is egy könyvtári szolgáltatás. Mindezt éjjelnappal, a hét minden napján megtehetik, így biztosítva rugalmasságot az olvasóknak a könyvtárak hagyományos nyitvatartásához képest.

Természetesen az online tartalomszolgáltatás felveti a jogszerü használat kérdését is, hiszen valahogy garantálni kell, hogy azok és csakis azok férjenek hozzá ezekhez a megvásárolt/előfizetett tartalmakhoz, akik a vásárló/előfizető intézmény felhasználói bázisának részét képezik. Erre az intézmény IP-tartományainak megadása a bevett módszer, hiszen a különböző egyetemi épületekben mind a PTEhez tartozó egyetemi polgárok tartózkodnak, akár dolgozói, akár hallgatói a jogviszonyuk, így adottak a jogszerü használat feltételei. Arra pedig minden résztvevő szigorúan ügyel, hogy kizárólag egyetemi hálózat IP-tartományai legyenek megadva a szolgáltatók felé. Igen ám, viszont ha az online tartalmak (egyik) vonzereje a 0-24-es elérésben rejlik, a hozzáférés viszont csak egyetemi épületekből oldható meg, akkor mi a megoldás abban az esetben, ha az illető egyetemi polgár nem ilyen épületben tartózkodik?

Itt jön be a távoli hozzáférés lehetősége. Ugyanis számtalan olyan helyzet adódhat, amikor nem „bent” dolgozunk, mégis szükséges hozzáférni a szakirodalomhoz, akár konferencián vagy kiküldetésen vagyunk, nyaralás közben jut eszünkbe egy világmegváltó kutatási téma, hallgatóként hazautazunk a hétvégére vagy egy szünetre, vagy akár csak kényelmesebb otthonról kutatni vagy dolgozni.

Ilyen távoli elérésre többféle mód is van, amelyeket az alábbi aloldalon mutatunk be: https://lib.pte.hu/tavoli_eleres, vagy Főoldal $\rightarrow$ E-könyvtár $\rightarrow$ Távoli elérés.

E-könyvtár
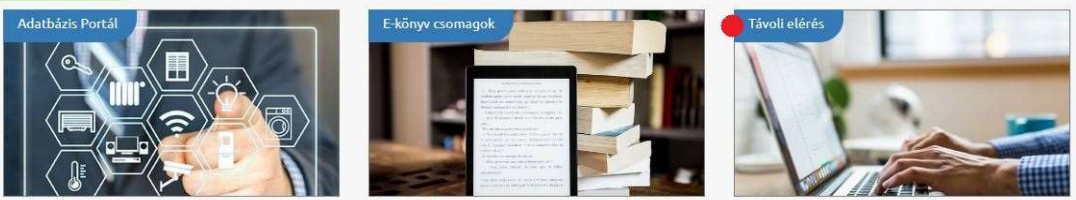


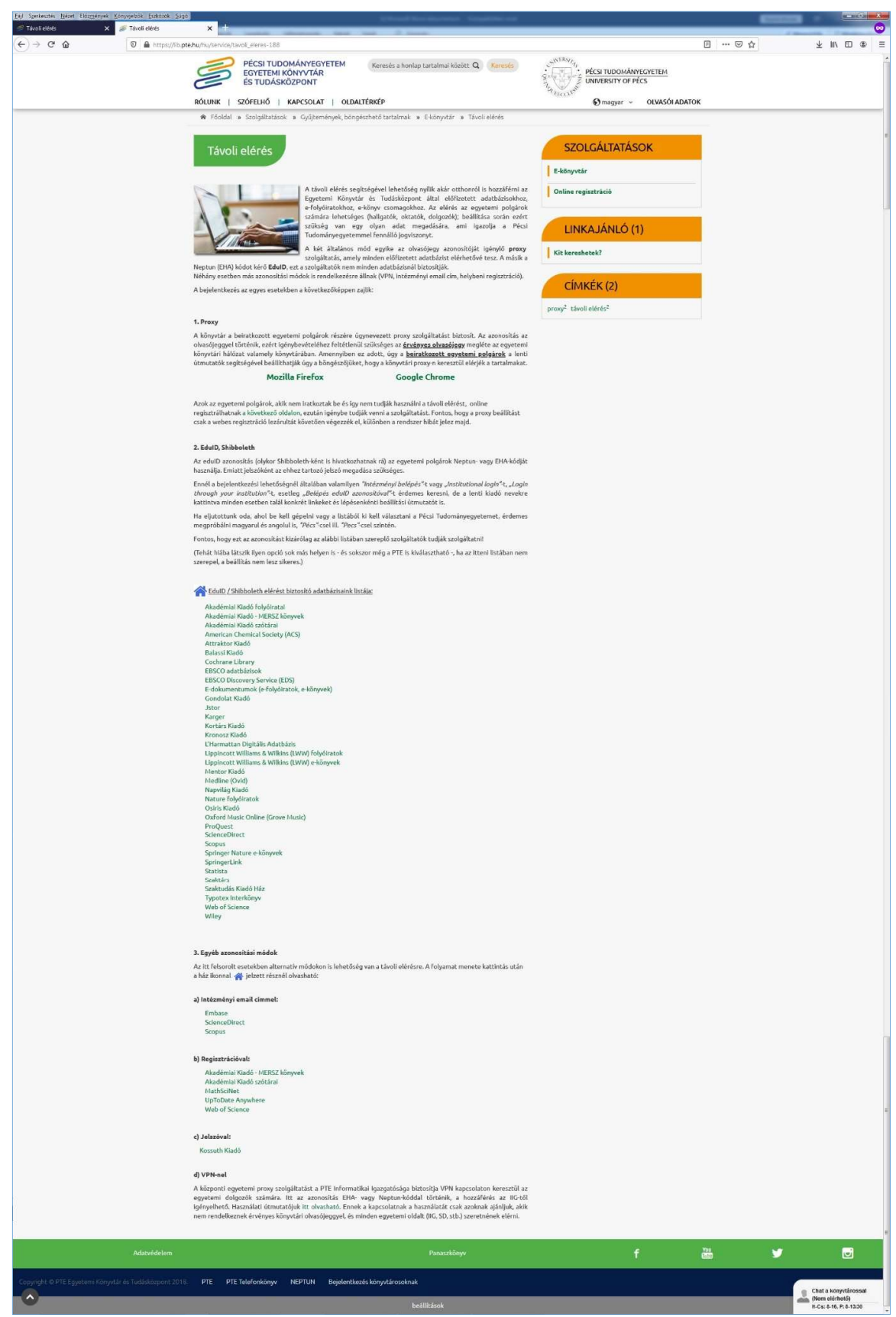

\section{Proxy}

Az egyik távoli elérési lehetőség a beiratkozott egyetemi polgárok részére a könyvtár proxy szolgáltatása. Ez nem ördöngösség, eszköztől függően az internetezésre használt eszköz internetkapcsolatát kell 
módosítani néhány beállítással, amely eredményeképp a felhasználó ugyanúgy tudja használni az eszközét, mintha egyetemi épületben tartózkodna. Természetesen a jogszerü használatot szükségszerüen ekkor is igazolni kell.

Az azonosítás az olvasójeggyel és az ahhoz tartozó jelszóval történik (alapértelmezetten születési hónap és nap, tehát $4 \mathrm{db}$ karakter), ezért igénybevételéhez feltétlenül szükséges az érvényes olvasójegy megléte a PTE egyetemi könyvtári hálózat valamely könyvtárában.

$\mathrm{Az}$ oldalon lépésenkénti guide-ok találhatóak magyar és angol nyelven is, amelyek részletesen, szöveges és képernyőképes formában is segítik a felhasználókat a proxy helyes beállításában, így ezek itt történő, részletes bemutatását mellőzném.

Segédlet Firefox böngészőhöz: https://bit.ly/3hXEmup

Segédlet Chrome böngészőhöz: https://bit.ly/3wDNd9D

Azok az egyetemi polgárok, akik nincsenek beiratkozva (és így nem tudják használni a távoli elérést), honlapunkon online regisztrálhatnak, majd jogviszonyuk igazolása után igénybe tudják venni a szolgáltatást. Fontos, hogy a proxy beállítást csak a webes regisztráció lezárását követően végezzék el, különben a rendszer hibát jelez.

\section{EduID, avagy Shibboleth}

Az eduID azonosítás (olykor Shibboleth-ként is hivatkozhatnak rá) az egyetemi polgárok Neptun- vagy EHA-kódját használja. Emiatt jelszóként az ehhez tartozó jelszó megadása szükséges.

Ennél a bejelentkezési lehetőségnél általában valamilyen „Intézményi belépés”-t vagy „Institutional login”-t, „Login through your institution"-t, esetleg „Belépés eduID azonositóval"-t érdemes keresni, de a távoli eléréses oldalunkon lévő kiadónevekre kattintva minden esetben konkrét linkek és lépésenkénti beállítási útmutatók is találhatók.

Fontos, hogy ezt az azonosítást kizárólag az oldalon szereplő szolgáltatók tudják szolgáltatni! (Tehát hiába látszik ilyen opció sok más helyen is - és sokszor még a PTE is kiválasztható -, ha a honlapunkon lévő listában nem szerepel, a beállítás nem lesz sikeres.)

Nézzünk egy példát, jelen esetben a ProQuest Central adatbázis Shibboleth-elérésének beállítására!

1. Nyissuk meg a következő oldalt: https://www.proquest.com/shibboleth 


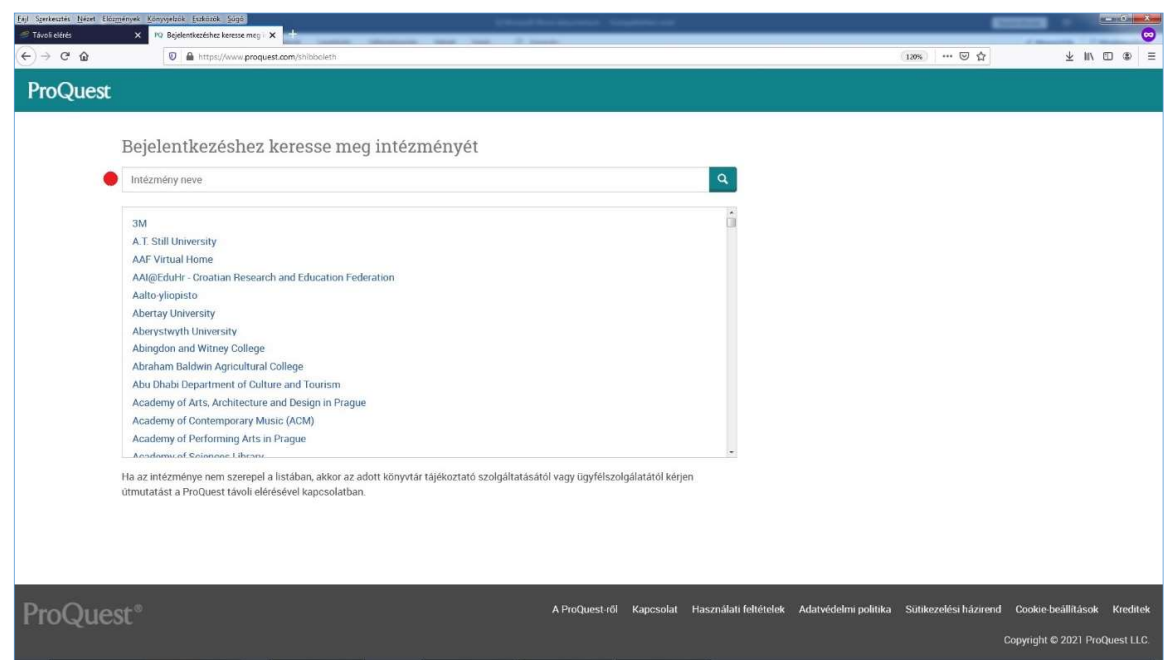

2. Második lépésben általában ki kell választani az intézményünket.

Általánosságban, ha eljutunk oda, ahol be kell gépelni vagy a listából ki kell választani a Pécsi Tudományegyetemet, érdemes megpróbálni magyarul és angolul is: a „Pécs” szóval, illetve az ékezet nélküli „Pecs” verzióval is. Jelen esetben mindkettő müködik.

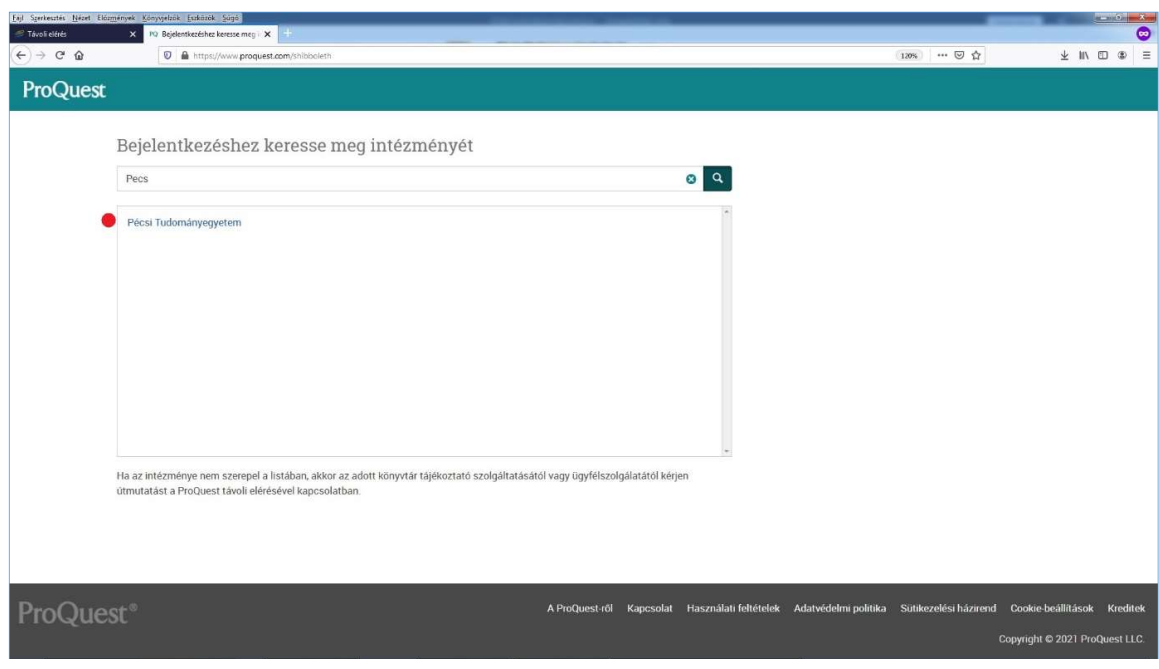

3. A Pécsi Tudományegyetemet kiválasztva a rendszer átirányít minket az azonosító oldalra, ahol meg kell adnunk a Neptunkódunkat, az ehhez tartozó jelszavunkat, majd a „Bejelentkezés" gombra kell kattintanunk. 


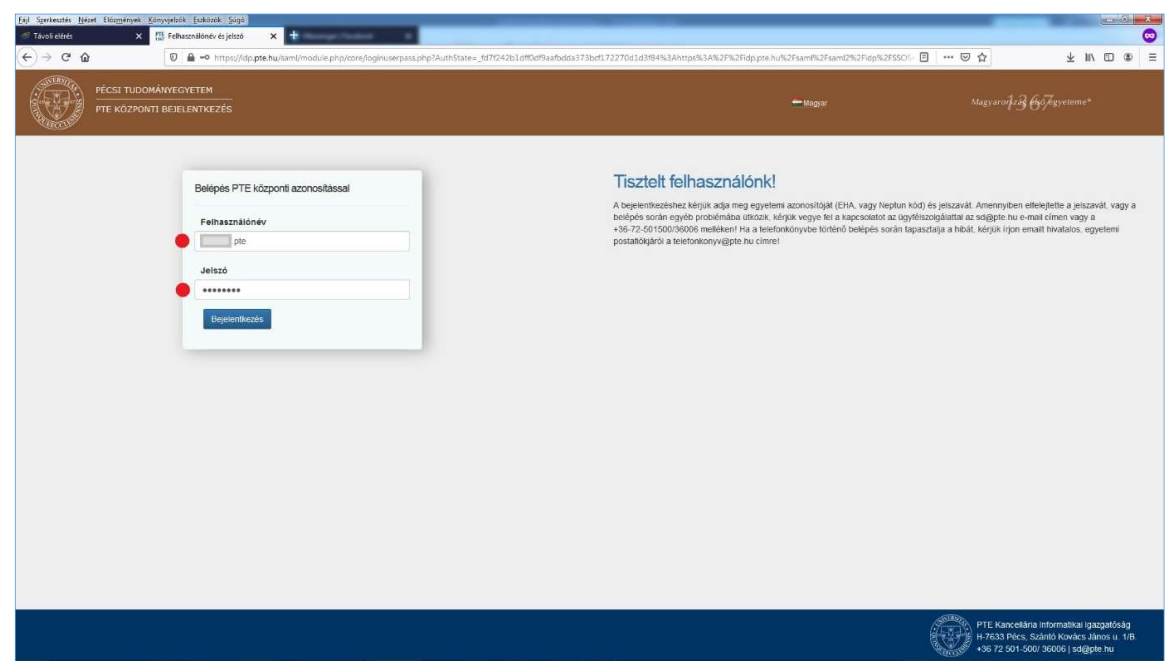

4. Ezután el kell fogadnunk az adatszolgáltatáshoz való hozzájárulást.

Ön azonositja magát ehhez a szolgältatáshoz: ProQuest PROD SP

$\mathrm{Az}$ azonositás során PTE Központi Névtár az alábbi adatokat fogja küldeni a szolgáltatásnak. Engedélyezi?

จ Emlékezzen a hozzájárulásra

Igen, elfogadom Nem, nem fogadom el

A szolgáltatás adatvádelmi nyilatkozata ProQuest PROD SP

5. Ezt követően el is jutunk az adott adatbázisunk kezdőlapjára, ahol árulkodó jelként meg szokott jelenni valamilyen formában a PTE neve, és/vagy a könyvtár logója. Általában ez mutatja (proxy esetében úgyszintén), hogy sikeres volt az azonosítás, és az adatbázis készen áll a használatra.

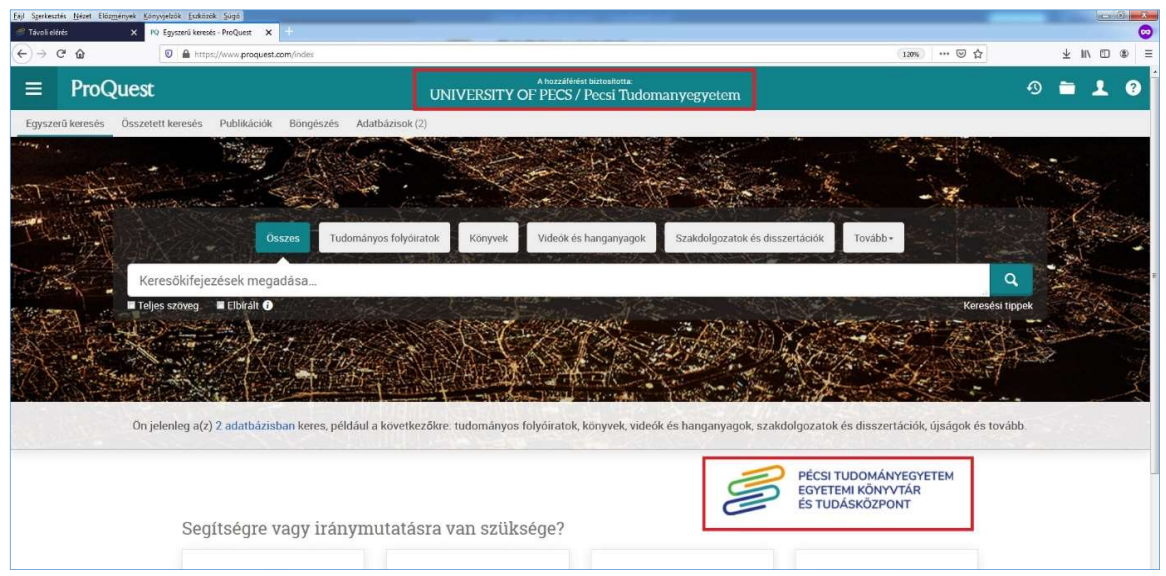




\section{Egyéb módok}

A fenti kettő a legelterjedtebb távoli elérési mód, ám egyes szolgáltatók további eszközökkel is hozzáférést nyújtanak szolgáltatásaikhoz. Van, ahol egy külön jelszót kell megadni (pl. Kossuth Kiadó), amit csak az információval felruházott személyek ismernek; van, ahol az intézményi e-mail-címmel való belépés is elegendő; de az alternatív módok közül talán a leggyakoribb az egyetemi hálózatból történő felhasználói fiók regisztrációja.

Ez esetben is csak annyit kell tennünk, hogy az egyetemi hálózaton tartózkodunk, majd az adatbázis oldalán regisztrálunk egy fiókot (más szóval létrehozunk egy account-ot) magunknak. Ezt követően, ha elhagyjuk a PTE területét, de ebbe a fiókba jelentkezünk be, szintén minden jogosultságunk meglesz a szolgáltatás használatához.

Ezen esetekben tehát csak az ellenőrzés után kiadható jelszó, az intézményi e-mail-cím, illetve az egyetemi hálózatról történő fiókregisztráció hivatott biztosítani, hogy kizárólag a jogosult felhasználók (azaz az egyetemi polgárok) használhassák távolról is az elektronikus tartalmakat. 


\section{5. ÁLTALÁNOS KERESÉSI STRATÉGIÁK ÉS MÓDSZEREK BEMUTATÁSA AZ ONLINE KÖNYVTÁRI KATALÓGUSON (WEBPAC) ÉS AZ EDS RENDSZEREN KERESZTÜL}

\section{Az már megvan, hogy miben keressünk - na de hogyan?}

Talán kezdjük inkább azzal, hogyan NEM érdemes keresni:

Omg opened my Nan's laptop and when she's googled something she's put 'please' and 'thank you'. I can't है है है

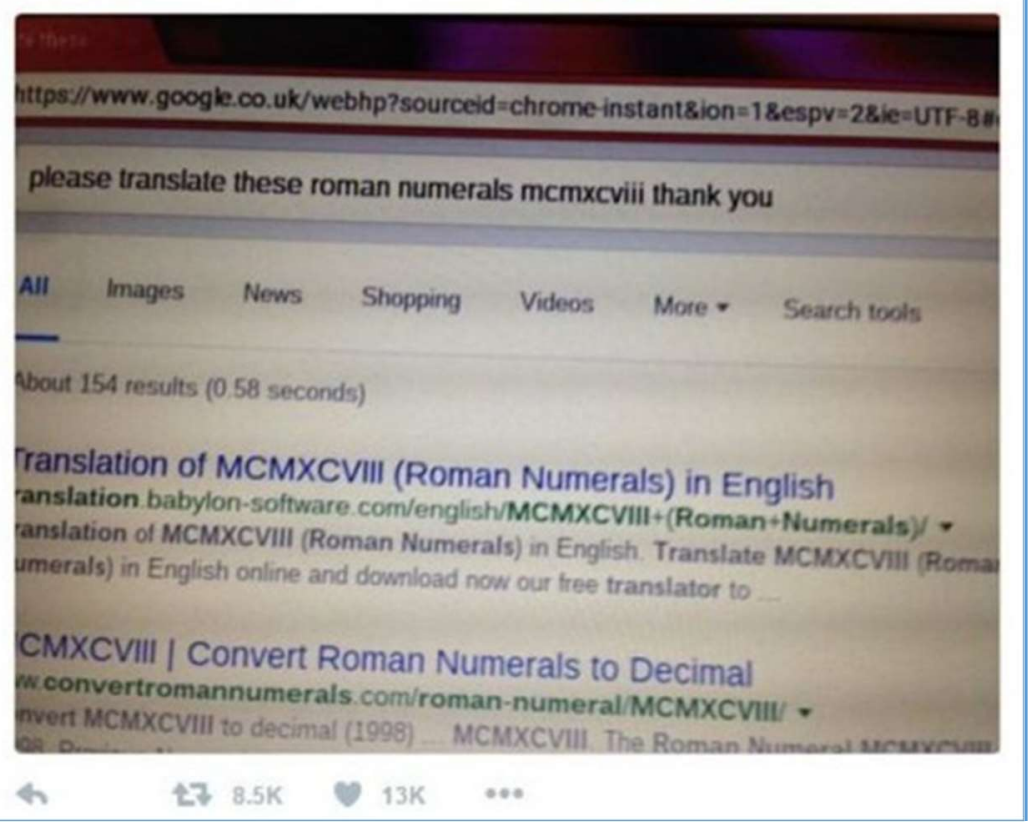

A fenti kép egy kedves példa arra, ahogyan egy nagymama egy Google-keresés során „kérem” és „köszönöm” kifejezéseket is használ, miközben azt a kérdést teszi fel, amelyet szóban is feltett volna. Ez természetesen nem a leghatékonyabb módszer. :-)

Általánosságban elmondható, hogy bár a keresőmotorok folyamatosan fejlődnek, és a mesterséges intelligenciával megtámogatott szoftverek kezdik megérteni a folyó szövegként, beszédszerüen feltett kérdéseket is, a leghatékonyabb - és sok adatbázis esetén az egyetlen igazán jó - módszer továbbra is a tárgyszavas keresés. 


\section{A kérdés és a releváns válasz}

Hogyan fogalmazzuk meg jól, amire kíváncsiak vagyunk, hogy valóban a kérdésünkre kapjunk választ?

Először is, a keresés mindig egy összehasonlítás. Ennek során a keresőkérdésünk által meghatározott halmazt hasonlítjuk össze azzal a halmazzal, amely leírja az adatbázisban tárolt adatokat, rekordokat, tehát gyakorlatilag halmazokkal végzünk müveleteket (illetve mi „csak” a saját halmazunkat állítjuk össze, a keresést általában a keresőmotorok végzik).

Belátható, hogy nagyon sok múlik azon, hogyan tesszük fel a keresőkérdést, azaz hogyan állítjuk össze a saját, majdan összevetendő halmazunkat, magyarán milyen szavakat, kifejezéseket írunk be a keresőmezőbe. Az összehasonlítás ugyanis akkor lesz sikeres, ha ugyanolyan módon fogalmazzuk meg a kérdésünket, ahogyan a válasz is rögzítve van.

A kifejezéseink legyenek egyértelmüek, és lehetőleg használjunk főnévi alakot. Továbbá maradjunk a kanonizált köznyelvi fordulatoknál, tehát például a tolvajnyelvet (pl. fü, lé, zsé stb.) mellözzük, mert „zajt” generál.

Példa 1: Horvátországba utazok nyaralni, és tudni szeretném, mi az ottani pénznem, és mennyi pénzt kell váltanom.

Többféle módon is elindulhatok: beírhatom a keresőbe (legyen az Google, Yahoo, Bing vagy bármi más), hogy „Horvátország pénznem”, vagy „horvát deviza”. Ezekre válaszul megkapom, hogy a hivatalos horvát pénznem a kuna, de még mindig nem tudom, magyar forintban lévő pénzemért mennyi kunát kapok. Ha viszont a fenti $2 \times 2$ kifejezésemet kiegészítem még azzal is, hogy ,árfolyam”, rögtön sorjáznak majd a különféle valutaátváltós honlapok árfolyamokkal, árfolyamtörténettel, lehetséges átváltási helyszínekkel. Mint látjuk, három egyszerü kifejezést használtam.

Példa 2: evezzünk egy fokkal tudományosabb vizekre. Tegyük fel, hogy pedagógia tárgyban keresek magyar nyelvü szakirodalmat, de nekem csak könyv jó. 2010 előtti kiadások már nem érdekesek számomra, és helyileg csak a BTK-TTK kari szakkönyvtár jöhet szóba.

Honnan tudhatom meg, vannak-e egyáltalán ilyen könyvek, amelyeket ráadásul ki is szeretnék kölcsönözni, föleg, ha csak késő este, otthon jut mindez az eszembe?

Nos, a legtöbb könyvtári katalógus, így a PTE könyvtári hálózatáé is online is elérhető, azaz szerencsére nem kell mindenképp be- 
menni valamelyik könyvtárba vagy betelefonálni ahhoz, hogy tudjuk, milyen dokumentumok vannak meg, és azok kölcsönözhetőek-e.

Katalógusunk (szaknyelven OPAC, azaz Online Public Access Catalog) elérhető a könyvtári honlap főoldalán vagy az alábbi linken is (persze ha ezek egyikét sem ismerjük, akkor csak beírjuk egy keresőbe, hogy „PTE könyvtár katalógus”, és voilá!): https://bit.ly/3tL4Lzw

Kattintsunk a linkre, és vessük bele magunkat az összetettebb keresések világába!

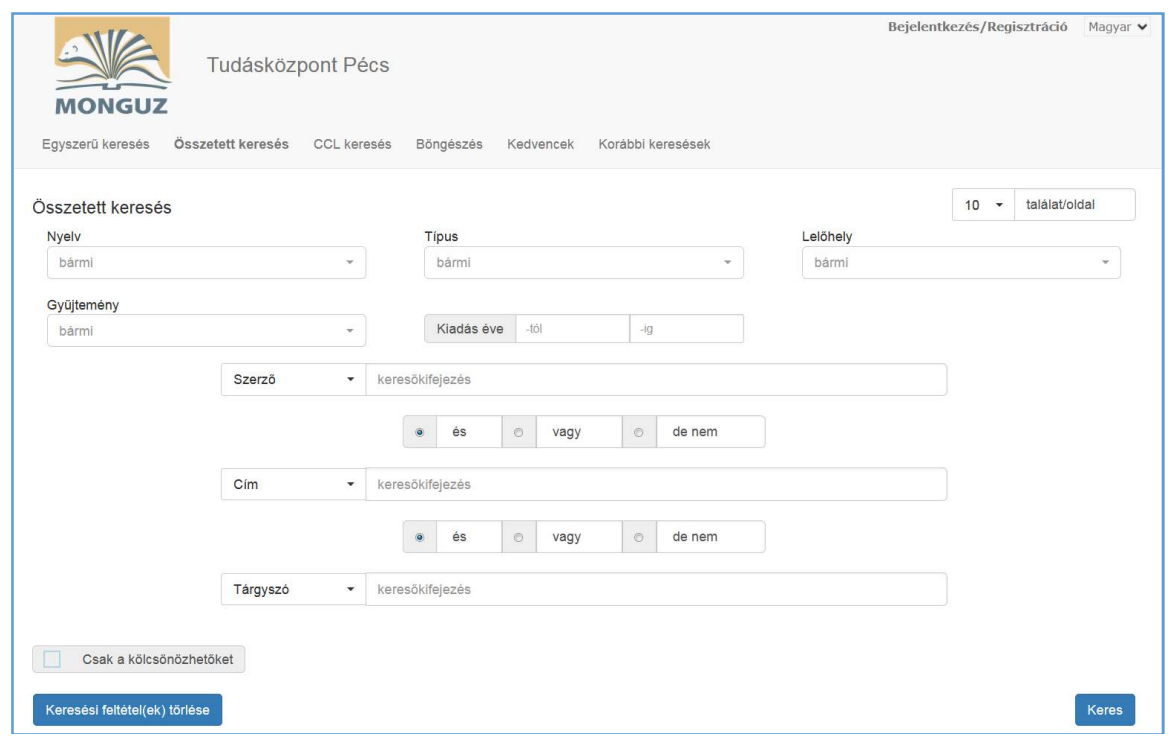

Itt már látható, hogy nem egy keresőmezőnk van, mint a nagy, népszerü, hétköznapi keresőknél, hanem több, elöre definiált szempontot figyelembe véve választhatunk legördülő menükből, és/vagy használhatunk szabadszavas mezőket. Tehát kérdésünk tárgyát több, apró részből kell összegyúrnunk, de szerencsére a szempontok eléggé magától értetődők.

\section{Mire van tehát szükségem? Mit keresek?}

2010 utáni, magyar nyelvü, a BTK-TTK könyvtárából kölcsönözhető, pedagógiai tárgyú könyvet. Vegyük végig, hogy ehhez miket kell beállítani a felületen: 


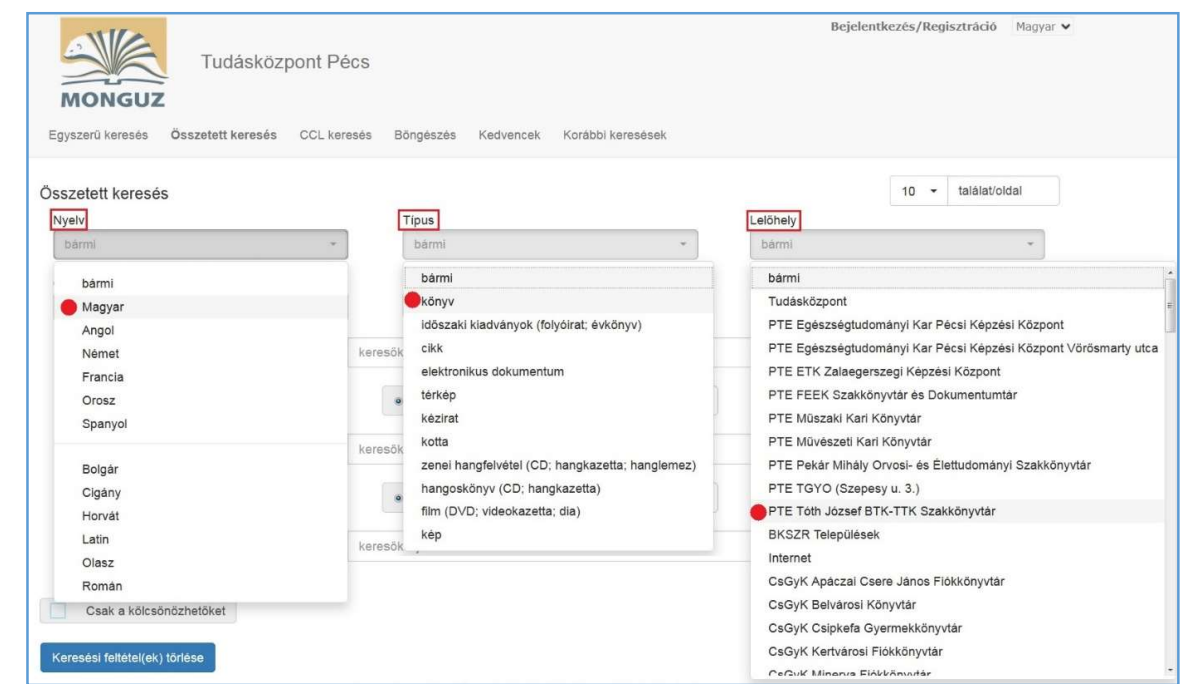

Ha végigmegyünk a lehetőségeken, a nyelvnél értelemszerüen kiválasztjuk a magyart, a dokumentum típusánál a könyvet, a lelőhelynél pedig megkeressük a BTK-TTK kari könyvtár hivatalos nevét, majd rákattintunk a PTE Tóth József BTK-TTK Szakkönyvtárra.

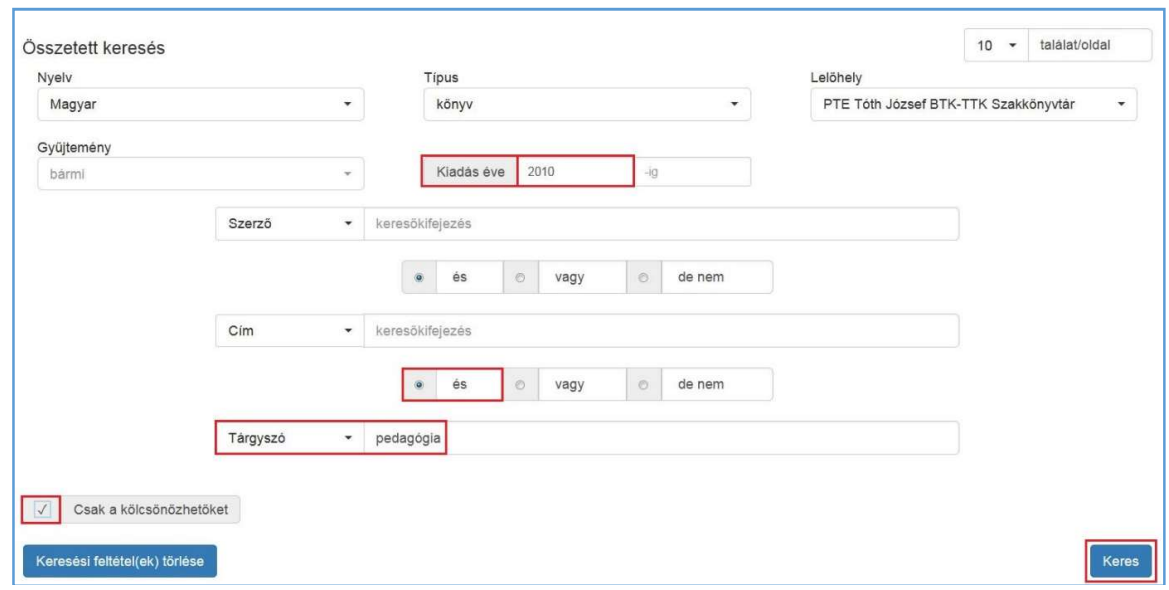

Hátravan még a 2010 utáni tulajdonság, a kölcsönözhetőség, illetve a tárgykör megadása. Ezeket a kiadás événél, a tárgyszónál, valamint a „Csak a kölcsönözhetőket” doboznál tudjuk beállítani.

A „Keresés” gomba kattintva a rendszer lekérdezi a megadott paramétereknek megfelelö találatokat, jelen tananyag készültekor 118 darabot. 


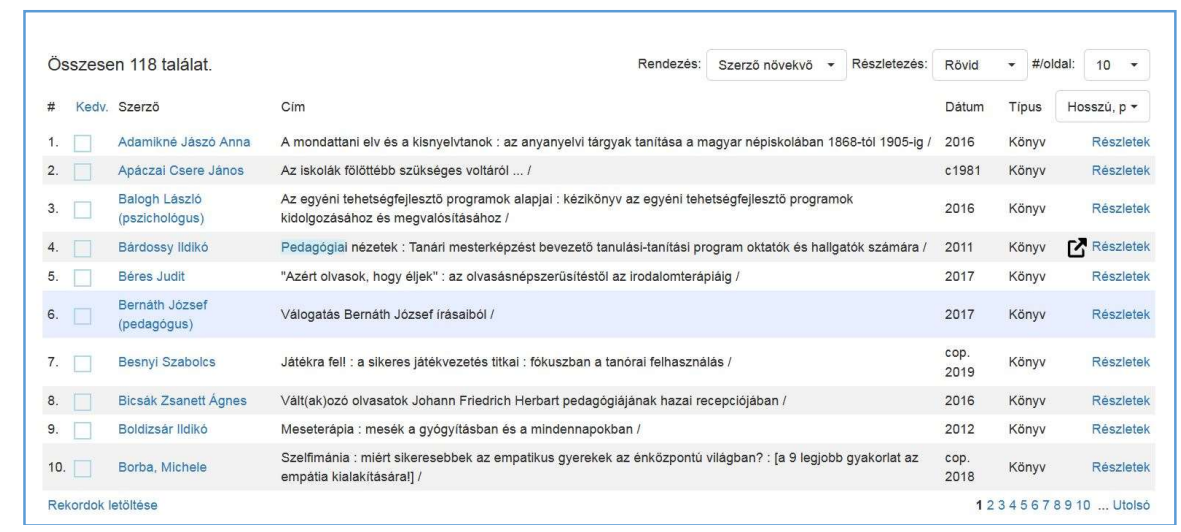

Aki figyelmes volt, annak feltünhetett, hogy az előző ábránál a szabadszavas mezőket tartalmazó sorok között volt három választható kifejezés: „és”, „vagy”, valamint „de nem”.

Itt nyer többszörösen is értelmet a korábban már említett tézis, miszerint halmazmüveleteket végzünk a keresések során. Ugyanis mit tettünk pontosan? Számos ismérv halmazát szúkítettük le az adatok megadásával (nyelv, típus, lelőhely stb.), majd az ezek révén összeálló közös halmazunkat vetettük össze a „Keresés” gombra kattintva a teljes katalógus halmazával. E két halmaz metszete, vagyis közös halmaza a listázott 118 elemet tartalmazza.

Ám ennél jóval bővebbek a lehetőségeink. Ugyanis általában lehetőségünk - sőt, olykor szükségünk is - van megadni a saját keresőkifejezéseink közti viszonyt is. Itt érdemes röviden bemutatni a leggyakoribb ún. Boole-operátorokat, amelyekkel megadhatjuk a halmazok közötti mủveleteket:

\section{1. ÉS (halmazok metszete, AND)}

- két vagy több halmaz közös elemeinek meghatározására való,

- megkapjuk mindazokat a dokumentumtételeket, amelyekben ismérvként ez a két szó együttesen előfordul,

- nem következik, hogy a két kifejezésnek egymás mellett, vagy akárcsak azonos sorrendben kell előfordulnia dokumentumon belül.

\section{VAGY (halmazok egyesítése, OR)}

- két vagy több halmaz összes olyan elemének meghatározására való, amelyekben az egyik vagy a másik, vagy mindkét kifejezés előfordul, 
- megkapjuk mindazokat a dokumentumtételeket, amelyekben vagy az egyik, vagy a másik kifejezés előfordul, de előfordulhatnak együtt is.

\section{DE NEM (halmazok kizárása, NOT)}

- az egyik halmaz elemeiből kizárja a másik halmaz elemeit,

- megkapjuk mindazokat a dokumentumtételeket, amelyekben az első kifejezés szerepel, de a második nem.

Logikus, hogy ezek a mủveletek alapjaiban befolyásolják a találati listánk nagyságát. Éppen ezért érdemes minél pontosabban megadni, mire vagyunk kíváncsiak, mivel egy több száz tételes listát nem fogunk tudni végigböngészni, föleg, ha közben csak a töredéke vonatkozik ténylegesen arra, amit keresünk. (Viszont könnyü abba a csapdába is beleesni, hogy túlspecifikáljuk a keresést, így pedig az ellenkező hatást érhetjük el: kisebb és könnyebben átnézhető lehet a listánk, viszont kimaradhatnak releváns találatok.)

Egy egyszerü példa a fenti három halmazmüveletre a „növény” és ,virág” szavakkal:

- „növény” AND „virág”: tartalmazza a növény ÉS a virág szavakat $\rightarrow$ szükebb találati halmaz,

• „növény” OR „,virág”: tartalmazza a növény VAGY a virág szavakat $\rightarrow$ jóval tágabb találati halmaz,

- „növény” NOT „,virág”: tartalmazza azokat a találatokat, amelyekben a növény szó szerepel, DE a virág szó NEM $\rightarrow$ szükebb találati halmaz.

Visszatérve az előző, pedagógiás példánkhoz, ha egy fokkal speciálisabb a keresésünk, a fentebb részletezett módokon ezeket is meg tudjuk adni a rendszernek, így pedig egészen változatos és összetett lekérdezéseket hozhatunk létre.

Az adott keresési feltételekre válaszul kaptunk tehát egy 118 tételes listát.

Viszont mi a teendőm akkor, ha ezek közül engem csak azok a dokumentumok érdekelnek, amelyek NEM az inkluzív pedagógiával foglalkoznak; hogyan kereshetem meg ezeket?

Nos, elöször is, használjuk ki a katalógus „Korábbi keresések” funkcióját a fejlécnél, így nem kell elölről kezdenünk az összes feltétel beállítását. 


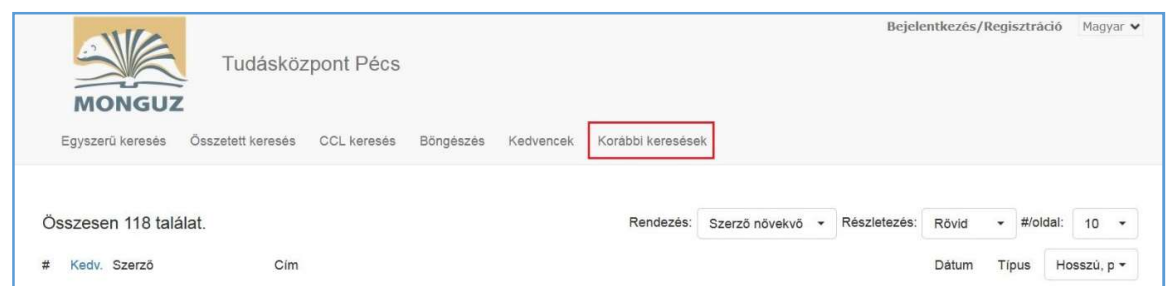

A képen is látható egyik legördülő menüböl szintén válasszuk ki a tárgyszó opciót, hogy kettő legyen belőle, majd írjuk be az elsőhöz azt, amit szeretnénk bent tartani a halmazban, a másodikhoz pedig azt, amit szeretnénk kizárni, majd a kettő közötti viszony megadásához válasszuk ki a „de nem” opciót.

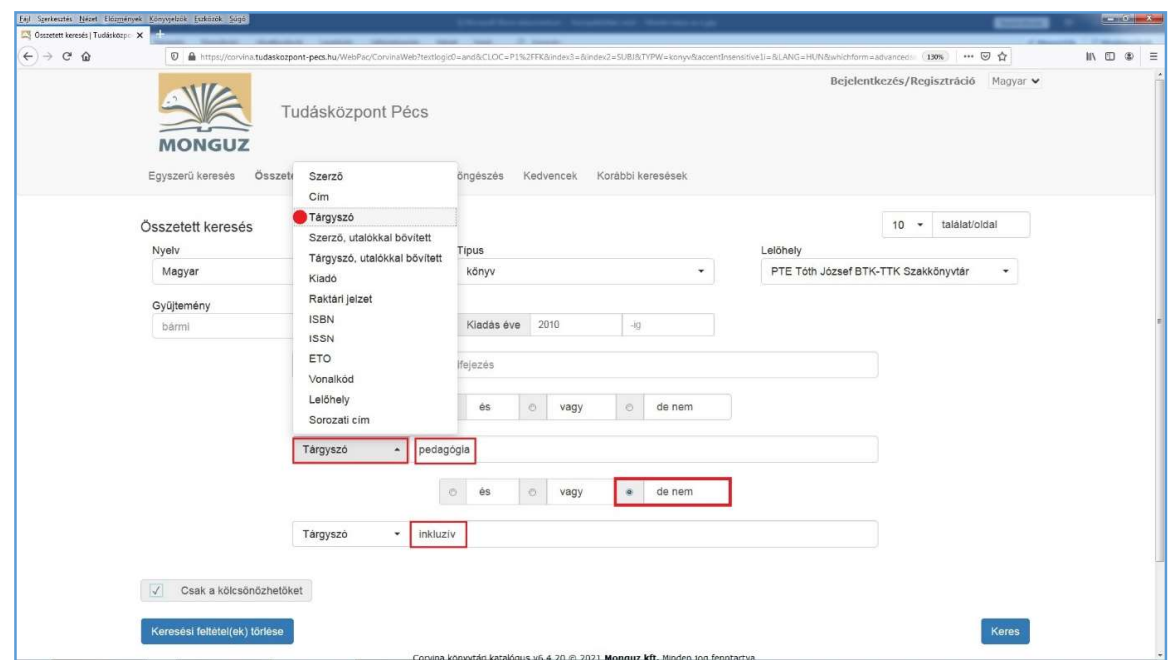

Ha mindent jól csináltunk, akkor 117 db találatot kaptunk, tehát 1 olyan tétel volt, amire igaz lett volna a „pedagógia” és az „inkluzív” tárgyszó is, és amit a keresésből így most kizártunk (megint csak a tananyag készítésének időpontjára igaz ez).

A fenti keresés a számos beállítási lehetőséggel természetesen egy összetett keresés volt, de ahogy a katalógusnak, úgy a legtöbb más keresőnek is van egy egyszerübb, egymezős felülete. A különbség az, hogy az összetett kereséseknél grafikusan tudjuk kiválasztani a kifejezések egymáshoz képesti viszonyát, míg a szimpla mezősbe nekünk kell beírnunk az operátorokat.

Ha csak egymás után, operátor nélkül gépeljük be a szavainkat (például a korábbi „horvát deviza árfolyam” keresésünk), akkor általában azt a rendszerek alapértelmezetten „ÉS” kapcsolatnak veszik. 
(Tipp: ha szükséges, az ilyen összetettebb keresések pl. a Google keresőből is elővarázsolhatóak, ott a Beállításoknál a „Speciális keresés" alatt található.)
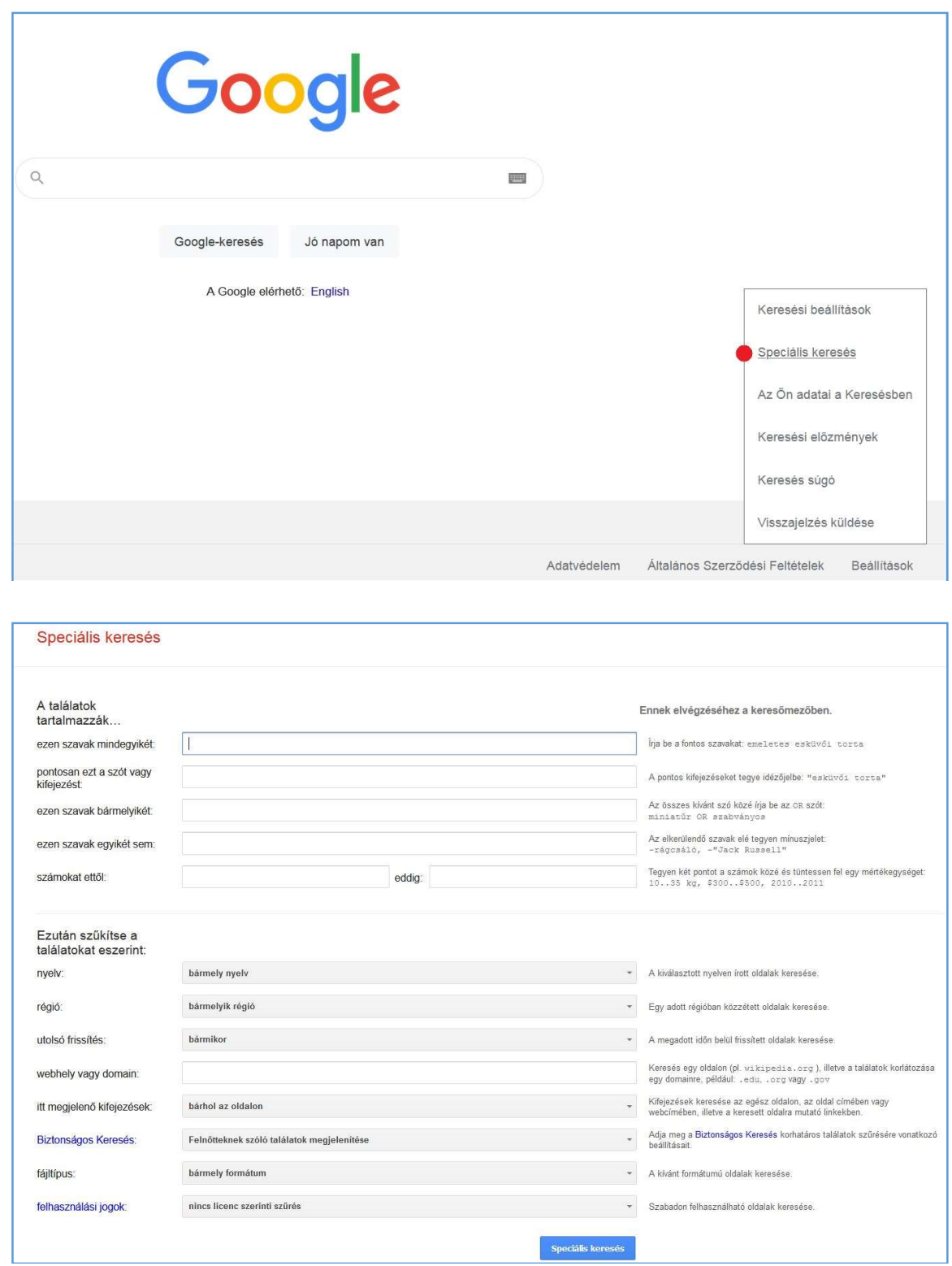


\section{Egyéb keresési lehetőségek: szótöredékek, jelhelyettesítés, idézőjelek}

A találati halmaz terjedelmét azzal is befolyásolhatjuk, hogy a keresőszó elejét, végét vagy azon belül meghatározott karakterpozíciókat nyitottá tesszük, azaz megengedjük, hogy a kifejezés elején, végén vagy meghatározott karakterpozícióin bármilyen karakter szerepeljen; ez az úgynevezett csonkolás és helyettesítés.

Ezeket különböző speciális - rendszerektől függően változó karakterekkel tudjuk engedélyezni.

Csonkolás: keresés szótöredékkel. A szó elején és/vagy végén álló meghatározott karakter minden megelöző és/vagy követő karaktert helyettesít. A találati halmazt értelemszerüen bővíti, ám nagyon hasznos, ha nem tudjuk, például egy szerző hogyan írja pontosan (helyesen) a nevét, vagy ha egy kereséssel több alternatív szóváltozatot is le szeretnénk fedni.

Katalógus: \%

EDS: *

Példák:

Schmi $\% \rightarrow$ találatok:Schmidt

Schmitt

Schmitz

Schmiedt

Schmiedlová

\%akács $\rightarrow$ találatok: Takács

Bakács

Szakács

Horváthné Takács

Hodossy-Takács

Hasznos nem csak neveknél, tárgyszavaknál is!

pedag $\% \rightarrow$ találatok: pedagógia

pedagógus

pedagógusképzés

pedagógiai szociol.

pedagógiai antrop. 
Helyettesítés: meghatározott karakter bármely karaktert helyettesít. A haszna ugyanaz, mint a csonkolásé, csak ez esetben a kifejezésen belül bővítjük a lehetőségeket.

\section{Katalógus:}

\section{EDS: ? (pontosan 1 karakter), \# (0 vagy 1 karakter)}

Példák:

$$
\begin{array}{ll}
\text { V_r_s } \rightarrow \text { találatok: } & \text { Varis } \\
& \text { Vároš (Milan) } \\
& \text { Veres } \\
& \text { Vörös } \\
& \text { Verks } \\
& \text { Verus (Siculus) }
\end{array}
$$

Idézőjelek közé téve: jelölhető, hogy a megadott többtagú, külön írt szavakból álló kifejezéseket, teljes szövegrészeket a rendszer egyetlen keresőszóként kezelje, azaz ne különálló, sok kis „AND” halmazunk legyen, brutális találati listákkal, hanem pont, hogy egy nagyon konkrét keresést eszközölünk, többnyire minimális találati számmal. Nagyon hasznos például, ha szövegben való előfordulást keresünk.

Példa: „Ég a napmelegtöl a kopár szík sarja...”

Összeségében tehát látható, hogy számtalan lehetőség áll rendelkezésünkre, hogy kérdésünket igazán pontosra formáljuk. Ugyanakkor a keresés lényegében egy heurisztikus eljárás: a feltalálás, a rájövés módszerének tudománya; ötleteken, tapasztalatokon és intuíción alapul. Elrontani nem lehet, kreatívan próbálkozni érdemes! 


\section{Az EBSCO Discovery Service, azaz az EDS}

\section{Mi az az EDS, és mi van benne?}

Az EDS az EBSCO adatbázis-szolgáltató cég egyik terméke, úgynevezett „felfedező eszköz”, vagy metakereső. Ez persze mind jól hangzik, de a gyakorlatban egy valóban jól használható összevont keresőt jelent, amely megkönnyíti, hogy a számtalan kisebb-nagyobb al-adatbázisban fellelhető adat egyetlen helyen elérhető legyen.

Ugyanis mint ahogy azt a tananyag elején megjegyeztük, a PTE-n viszonylag sok adatbázis használható, ezek egy része előfizetett, a többségük pedig ingyenesen hozzáférhető tartalom. Viszont mitévő legyek, ha mondjuk a sejtosztódásról, vagy mondjuk a gravitációs hullámokról szóló legfrissebb szakcikkekre lenne szükségem?

Nézzem át egyesével az összes, az Adatbázis portálon feltüntetett adatbázist, és futtassam le mindben egyesével ugyanazt a keresést? (Ha még emlékszünk ugyanitt a szakterületi listázási lehetöségre, még akkor is a kelleténél több helyen kellene kutakodnunk a kívánt anyag után.)

Nos, az EDS ezt a problémát hivatott áthidalni: amit csak lehet, integrálunk bele, így a keresés egy helyen, de az összes integrált adatbázisban egyszerre történik. A teljes szövegü cikkekhez pedig direkt link vezet, így ha keresünk valamit az EDS-ben, amit a rendszer mondjuk a Nature-nél talál meg, akkor átirányít minket a Nature saját oldalára, ahol elolvashatjuk a kívánt cikket (már ha van rá előfizetésünk természetesen.)

Mik találhatóak az EDS-ben:

- EBSCO által szolgáltatott (és megvásárolt) adatbázisok

- Academic Search Complete

- Econlit Fulltext

- MathSciNet

- Business Source Premier

- Stb.

- EBSCO által kiválasztott ingyenes, Open Access, minőségi, egyéb adatbázisok (pl. Associated Press videók) 
- A PTE által vásárolt, és az EBSCO felé lejelentett adatbázisok

○ SpringerNature folyóiratok

○ Wiley Online Library

- ScienceDirect

- Stb.

- Egyéb faktografikus tartalmak, widgetek

- Akadémiai Kiadó szótárai

- UptoDate

- Arcanum Digitális Tudománytár

- EMBASE

- Pécsi Egyetemi Archívum (PEA)

○ Digitália

○ Stb.

- Repozitóriumok, preprint szerverek

- E-book gyüjtemények

- A könyvtár katalógusa (!)

Tehát röviden: az EDS-ben gyakorlatilag minden elöfizetett adatbázis tartalma elérhető. A teljesszövegü adatbázisok a cikkekre mutató hivatkozásokkal (és természetesen bibliográfiai adatokkal), a nem ilyen típusú tartalmak pedig widgetekkel. Mivel ugyanakkor a legtöbb tudományos tartalom angol nyelvü, ne lepődjünk meg, hogy az EDSben is jobbára angol nyelvü találatokat fogunk kapni.

Rendkívül hasznos funkció továbbá, hogy - az e-könyv csomagjainkon kívül - a könyvtár katalógusát is ismeri a rendszer, tehát a nyomtatott könyvtári állományra mutató találatokat is kapunk.

Az EDS-kereső elérhető az Adatbázis portálról az adatbázisok listájából, de szintén ki van vezetve az oldalra is egy keresődoboz formájában. Ez az a kék doboz, amit korábban említettünk, és amire most térünk vissza. Ennek a keresődoboznak a használata gyorsabbá teszi a keresést, tehát használjuk nyugodtan! 


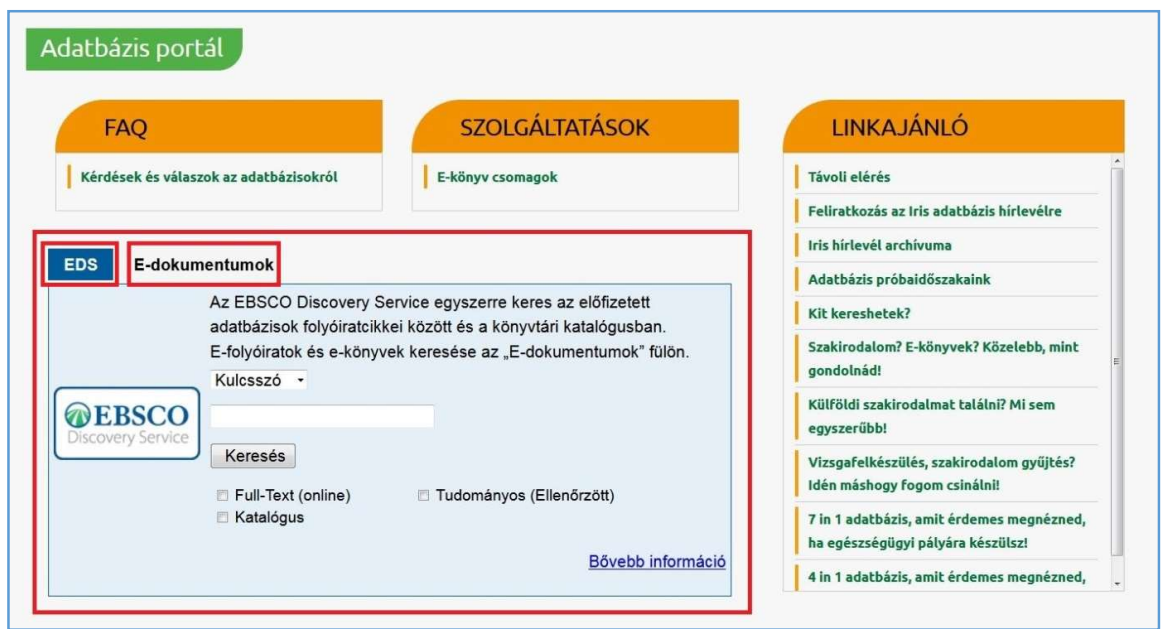

Mint látható, a doboznak két „füle” van: egy „EDS” és egy „Edokumentumok". Ezek közül az EDS való arra, hogy cikkeket, publikációkat keressünk, az E-dokumentumok pedig arra, hogy konkrét folyóiratot vagy e-könyvet, tehát kiadványt.

Nézzünk egy példát: keressünk rá az EDS-ben a gravitációs hullámokra!

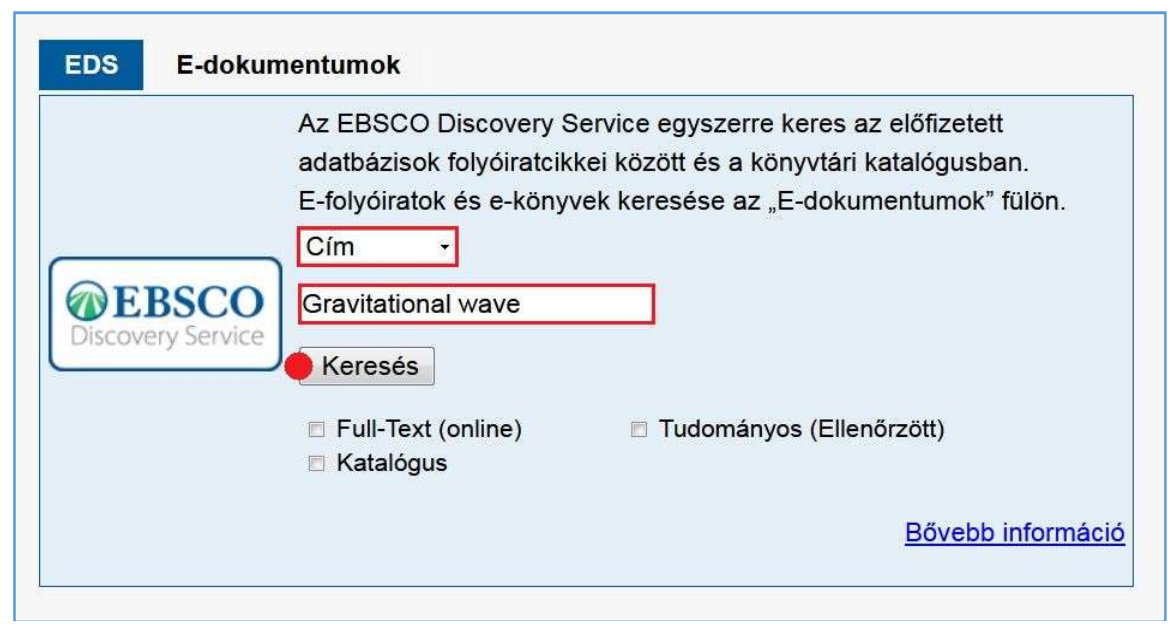

Kiválasztva a „Cím”-et, beírva a keresőkifejezést, majd a keresésre kattintva a következő felületen láthatjuk a találatokat: 


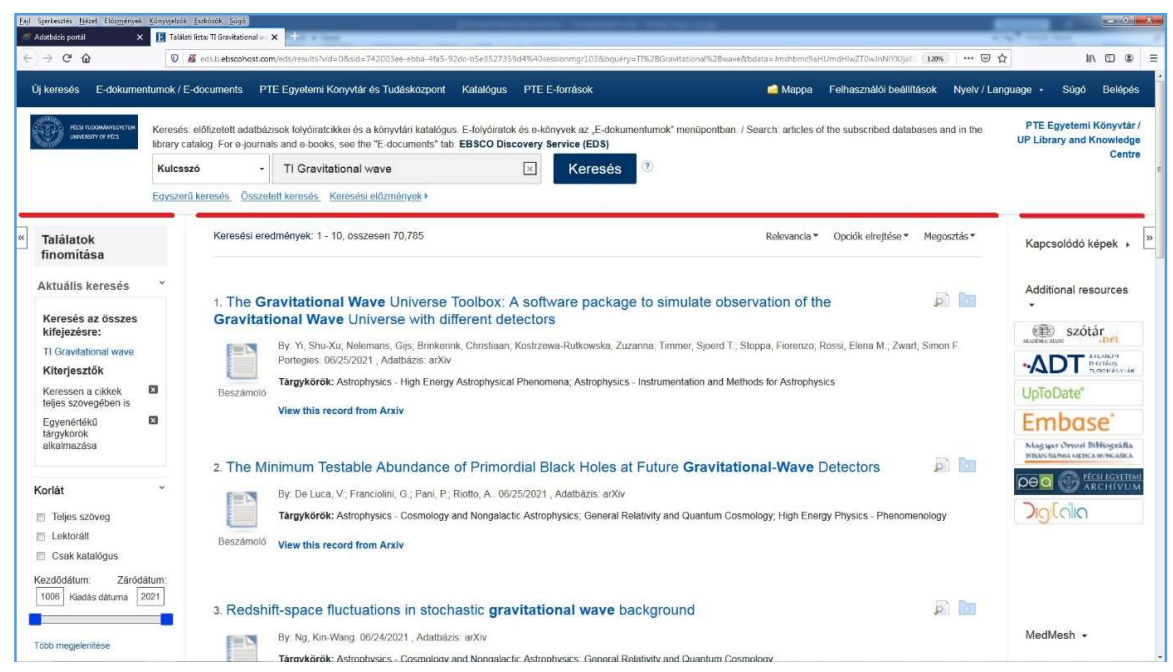

A találati oldalon három oszlop különíthető el: bal oldalon a különböző ún. limiterek, amelyekkel finomíthatjuk, szükíthetjükbővíthetjük a keresésünket, középen maguk a találatok, jobb oldalt pedig a már említett widgetek. A legtöbb tudományos adatbázis egyébként hasonló dizájnt használ, tehát máshol is találkozhatunk ilyen felépítéssel.

Vessünk egy pillantást a limiterekre!

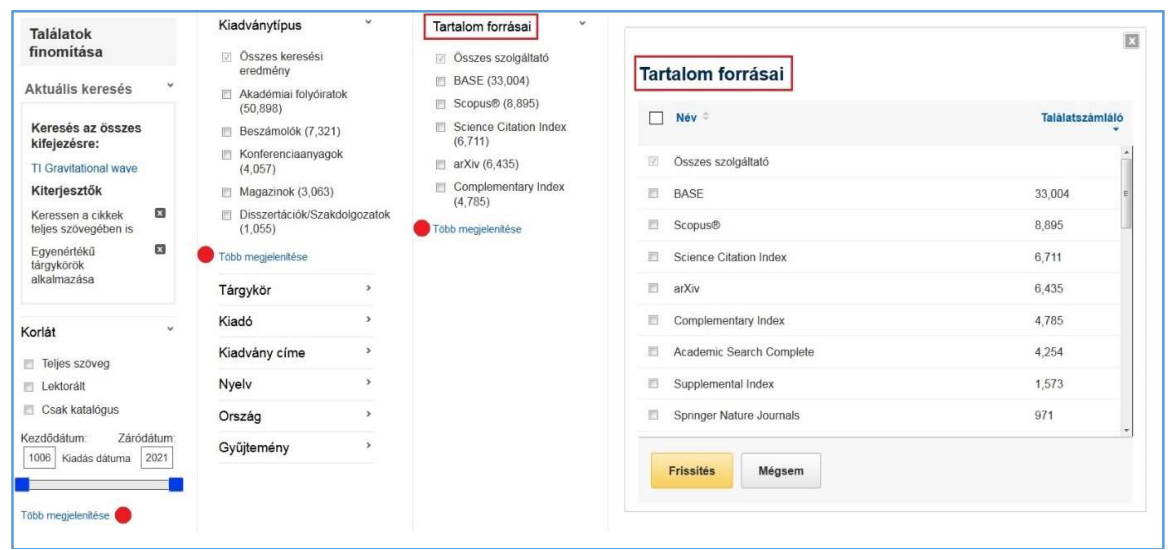

Ezeknél gyakorlatilag ugyanazokat a paramétereket tudjuk beállítani, mint amiket egy összetett keresés során elöre is megadhatunk, legyen szó arról, hogy csak teljes szövegü cikkekre vagyunk-e kíváncsiak, vagy absztraktok is elegendőek, tudományosan lektorált forrásokban megjelent cikkekre van-e szükségünk (ez egyébként ajánlott), vagy mikori kiadású legyen a számunkra kívánatos szakirodalom. 
Ezeken kívül szürhetünk még kiadványtípusra, tárgykörre, kiadóra, címre, nyelvre, országra, gyüjteményre és a tartalom forrásaira is. Minden kategóriánál látszik egy „Több megjelenítése” lehetőség is, erre kattintva értelemszerúen még mélyebben belemerülhetünk az adott kategória lehetőségeibe (alapértelmezetten csak a legnagyobb halmazzal bíró néhány lehetőség jelenik meg az átláthatóság érdekében).

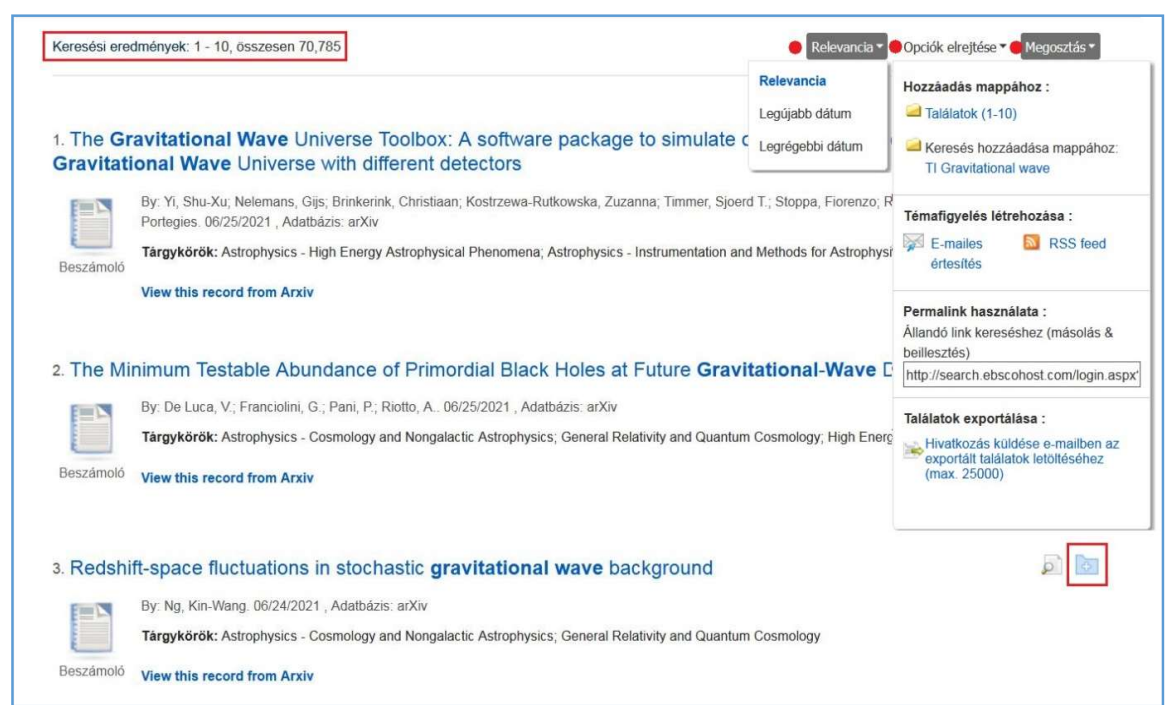

A középső, találatokat bemutató oszlopban látható, hogy a szürők nélküli keresésünk $70.785 \mathrm{db}$ találatot adott ki a gravitációs hullámokra, amelyek közül az oldal az első 10 találatot jeleníti meg. A találatokat rendezhetjük relevancia vagy dátum alapján, a kinézetet testre szabhatjuk az opciók elrejtésénél, a komplett listát pedig megoszthatjuk másokkal is, valamint beállíthatunk témafigyelést is az adott keresésre.

Van továbbá egy kis kék mappa ikon is, amellyel az adott találatot egy saját mappához adhatjuk hozzá (ehhez érdemes regisztrálni egy ingyenes felhasználói fiókot).

A legelső találatot vizsgáljuk meg tüzetesebben is!

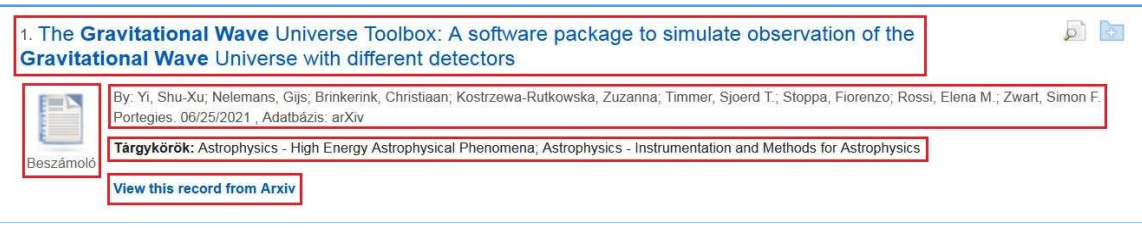

Láthatóak a különböző adatpanelek (cím, találat típusa, szerzőségi és megjelenési adatok), valamint a korábban már többször említett di- 
rekt link is: ha rákattintunk a „View this record from Arxiv”-linkre, akkor eljutunk az ArXiv oldalára, ahol megnyithatjuk és adott esetben - például most is - letölthetjük a beszámolót; ilyenkor érdemes egy PDF letöltés opciót keresni a szemünkkel.

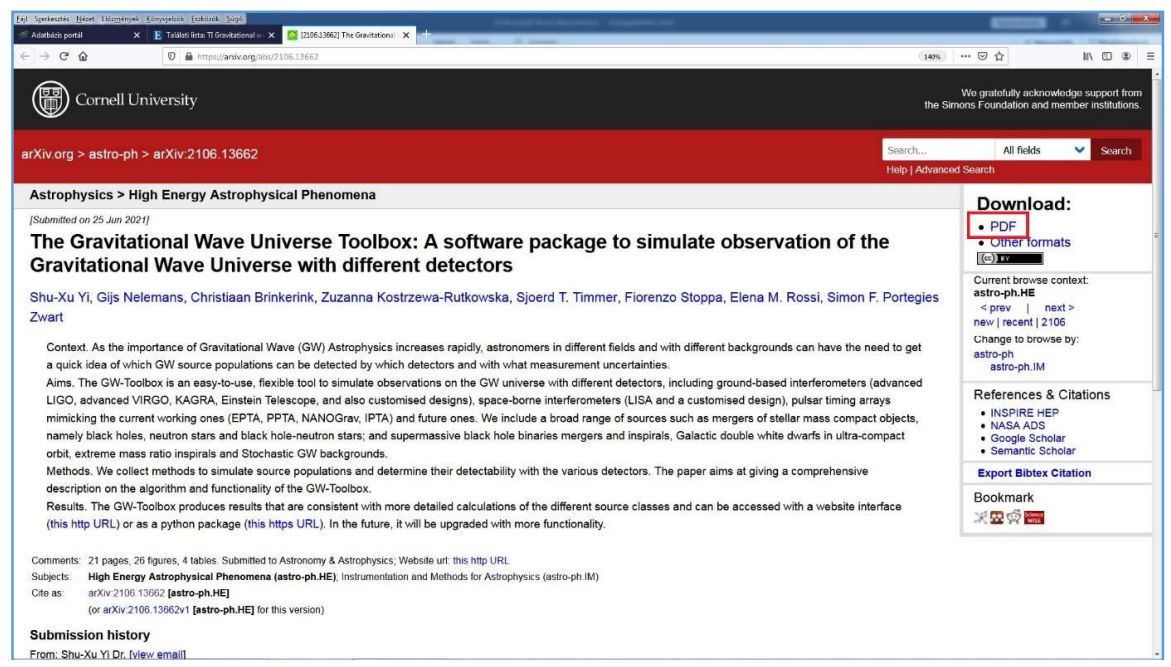

Ha pedig az EDS-beli találatoknál egy találat címére kattintunk, akkor egy új ablakban annak a találatnak a részletes adatai jelennek meg:

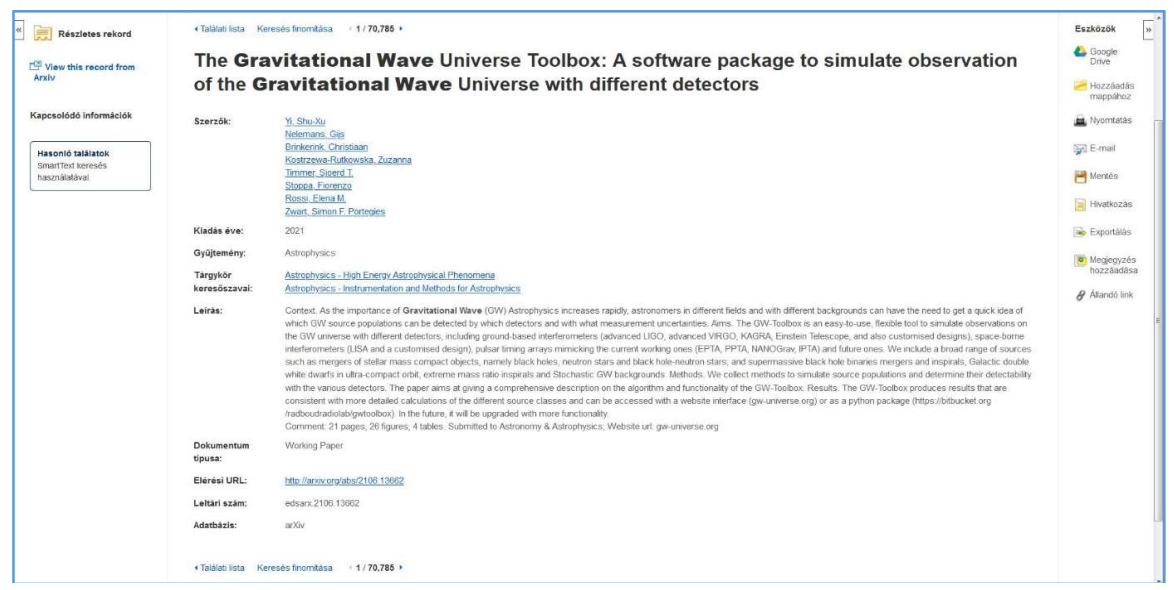

Ez annyiban más, mint a kettővel ezelőtti ábra, hogy a szerzők és a tárgykör keresőszavai itt már hivatkozások - azaz ezekre kattintva átnyergelhetünk egy másfajta keresésre, például ha a cikk fő szerzőjének, Shu-Xu Yi-nek további munkásságára vagyunk kíváncsiak, rákattintva rögtön meg is keresi nekünk ezeket a rendszer. 
Látható továbbá az adott cikknek a rövid leírása (absztraktja), ami segít nekünk eldönteni, releváns-e számunkra a cikk. Ha igen, akkor elmehetünk a teljes szöveghez (bal oldalt, vagy középen az elérési URL-re kattintva), ha pedig nem, akkor mehetünk a következö találathoz.

Jobb oldalt további eszközök is rendelkezésünkre állnak: Google Drive-fiókunkba exportálhatjuk a rekordot, mappázhatjuk, nyomtathatjuk, megoszthatjuk e-mailben vagy állandó linkkel, vagy rögtön készíthetünk hozzá különböző stílusokban hivatkozásokat is, ha például irodalomjegyzékbe szeretnénk illeszteni.

Természetesen $70.785 \mathrm{db}$ találat a gravitációs hullámokra rengeteg, de legalábbis több annál, mint amit fel tudnánk dolgozni, tehát mindenképp érdemes megfelelően szükíteni a keresést, akár a limiterekkel, akár már előre beállítani halmazszükítő szempontokat az összetett keresésnél.

Az összetett keresésre kattintva egyébként hasonló logika fogad minket, mint korábban az online könyvtári katalógusnál is láttuk:

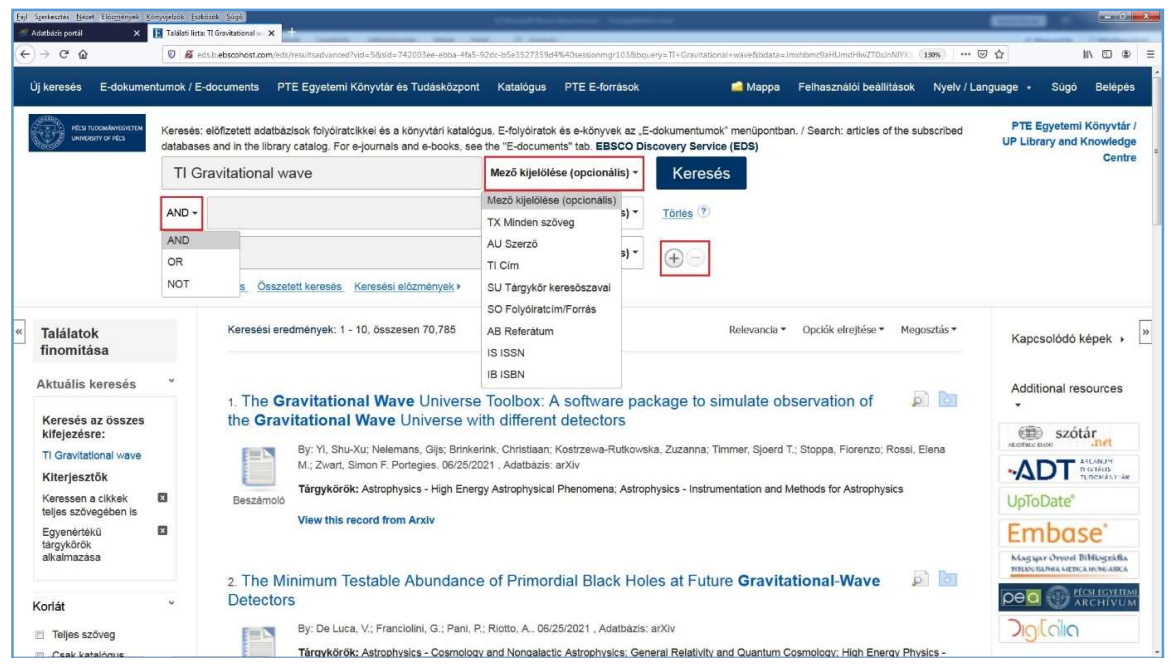

Ki tudjuk választani az adott szöveges mezö fajtáját (minden szövegben keressen, csak szerzőben, címben stb.), megadhatjuk a mezők közötti relációt (AND, OR, NOT), a + - gombokkal pedig még több mezőt adhatunk a kereséshez, vagy eltávolíthatjuk őket.

Utolsó pontként lássunk még egy képet az E-dokumentumokról is! Tegyük fel, hogy a Nature Microbiology címü folyóiratot keressük. Adjuk meg az adatbázis portálon lévő keresődoboz E-dokumentumok fülénél ezt a címet! 


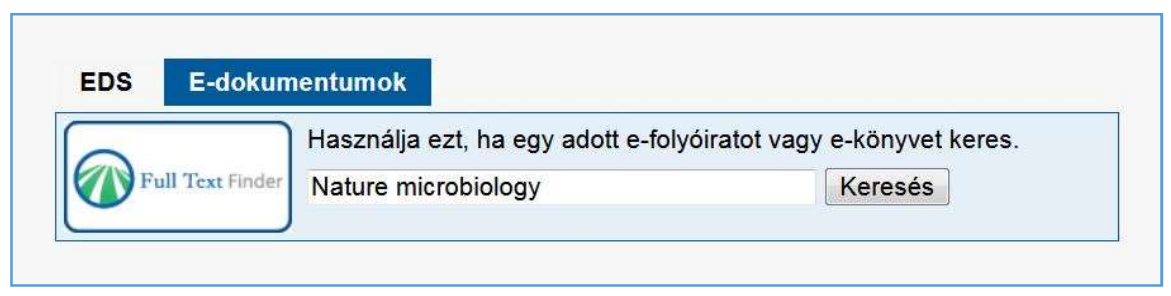

A keresésre kattintva a rendszer megjeleníti nekünk azokat a folyóiratokat vagy e-könyveket, amelyek címében szerepel az általunk keresett kifejezés.

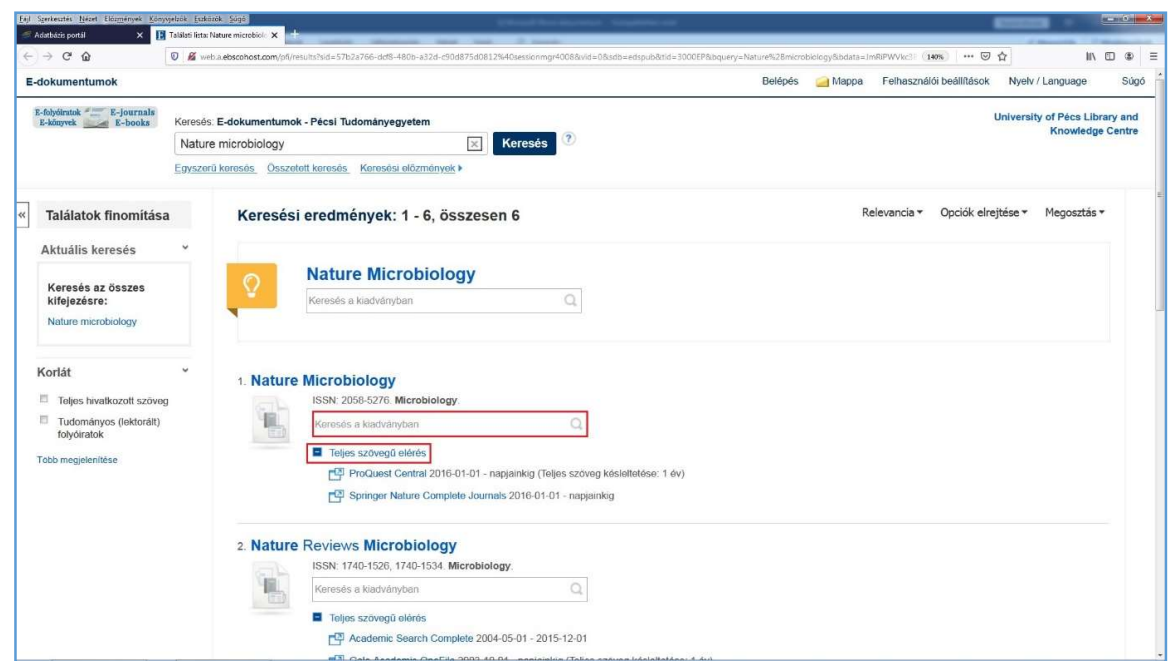

$6 \mathrm{db}$ találatunk van, a legelső pedig valóban az, amit kerestünk is. Itt lehetőségünk van már csak ebben a konkrét kiadványban keresni, illetve láthatjuk a különböző teljes szövegü opciókat is, amelyek egyúttal arról is tájékoztatnak, hogy miben található, és mettől meddig tart az időbeli lefedettség. Esetünkben a ProQuest Centralban 2016tól kezdve érhetőek el a Nature Microbiology számai (a legutolsó egy évet leszámítva), valamint a kiadói oldalon szintén 2016-tól kezdve, viszont már az ún. embargo nélkül, tehát a legfrissebb, kurrens számokhoz is van hozzáférés. Ezek továbbra is linkek, tehát rákattintva eljutunk a tényleges tartalomhoz. 


\section{ZÁRÓ SZAVAK}

Jelen tananyagban igyekeztünk részletes, ámde a mindennapok során is használható betekintést adni az egyetemi könyvtár által beszerzett és üzemeltetett felületek bemutatása révén azokról a lehetőségekről, amelyeken keresztül elektronikus formában is támogatni igyekszünk az egyetemi polgárság szakirodalom- és dokumentumigényét.

Reméljük, hogy tudtunk újdonságot mondani, és tananyagunkat szükség esetén mankóként használva pedig sikerrel birkóznak majd meg az egyetemi élet során jelentkező lankadatlan információéhség jelentette kihívásokkal.

Ehhez kívánunk sok sikert és kitartást!

Végezetül pedig egy könnyed hangvételü (Kahoot) ismétlés: https://bit.ly/3hyKAlt (A linket a böngészőbe másolva bejelentkezés nélkül, vendégként is végigjátszható!)

\section{Hasznos linkek:}

- https://lib.pte.hu

- https://lib.pte.hu/adatbazisok

- https://lib.pte.hu/e-konyvcsomagok

- https://lib.pte.hu/tavoli_eleres

- https://api.lib.pte.hu/api/hirleveleink

- https://compass.mtak.hu

- https://my.lib.pte.hu

- https://kalauz.lib.pte.hu 